\title{
الحوار المذهبي: مفهومه، ومنطلقاته، وضوابطه
}

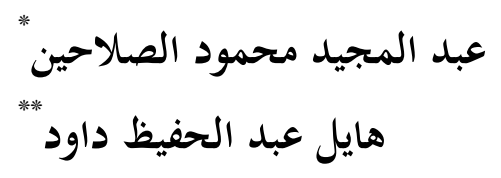

$$
\begin{aligned}
& \text { الملخص } \\
& \text { يهدف هذا البحث إلى بيان مفهوم الحوار المذهبي والأسس التي يبنى عليها، والضوابط التي تعين في تحقيق }
\end{aligned}
$$

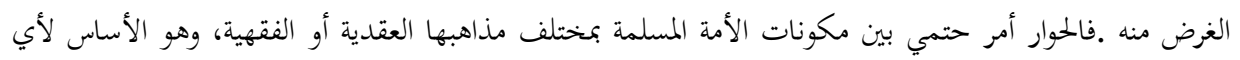

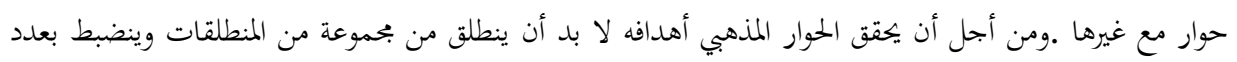

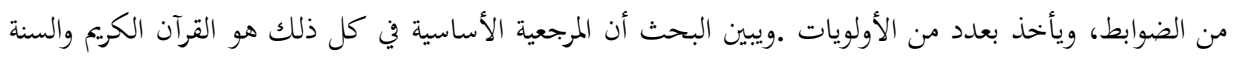

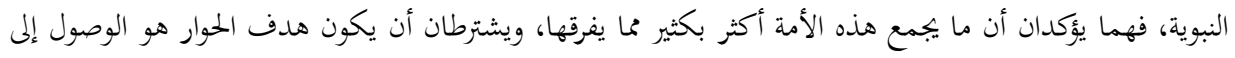

$$
\begin{aligned}
& \text { الحقيقة وليس الانتصار للمذهب بلا حقّ أو الباطل. } \\
& \text { الكلمات المفتاحية :مفهوم الحوار المذهبي، منطلقات الحوار المذهبي، ضوابط الحوار المذهبي، أولويات الحوار } \\
& \text { المذهبي، الاختلاف المذهبي. }
\end{aligned}
$$

\section{Inter-Sectarian Dialogue: Its Concept, Foundations, and Conditions}

\section{Abstract}

This study aims to examine the concept of inter-sectarian dialogue among Muslims, and illustrate the foundations, conditions, and priorities of a successful dialogue. Dialogue among Muslims of various jurisprudential schools and doctrinal sects is inevitable, and is the foundation for any dialogue with others. In order to achieve its purposes, dialogue should stem from certain premises, controlled by certain conditions, and take a number of priorities. The study explains how the Holy Qur'an and Noble Sunnah constitute the frame of reference and the guiding authority for this dialogue, as they both affirm that which unites the Muslim Ummah together is much more than what divides it. This authority requires also that the objective of dialogue should be the search for the truth and not to defend a position, whether right or wrong.

Keywords: Concept of Inter-Sectarian Dialogue, Premises of Inter-Sectarian Dialogue, Conditions of Inter-Sectarian Dialogue, Priorities of Inter-Sectarian Dialogue, Disagreement among Schools of Thought/Sects.

$$
\begin{aligned}
& \text { * دكتوراه في الفقه وأصوله، جامعة أم القرى، أستاذ الفقه وأصوله في كلية الشريعة- الجامعة الأردنية. البريد الإلكتروني: } \\
& \text { a.salaheen@yahoo.com }
\end{aligned}
$$

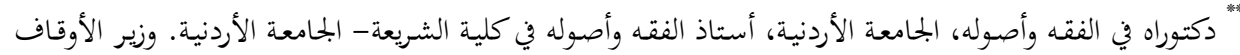

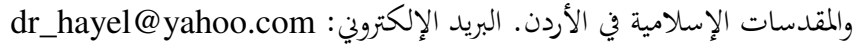

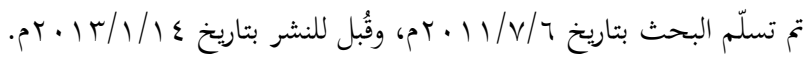




\section{مقدمة:}

حَفَل القـرآنُ الكـريم بحوارات متعـددة على مستويات مختلفـة متباينـة، كما سـجَّلت

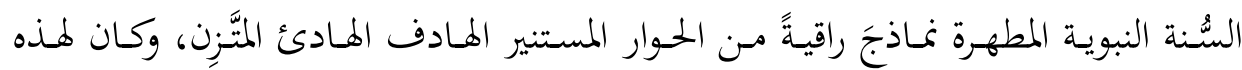
النماذج مع حوارات القرآن الكريم أكبر الأثر في استجابة النَّاس لمذا الدِّين. وإنَّ المتتبِّع

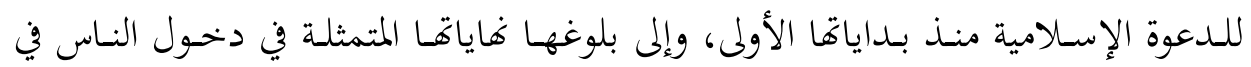

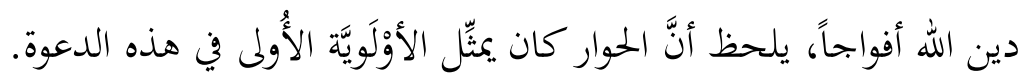

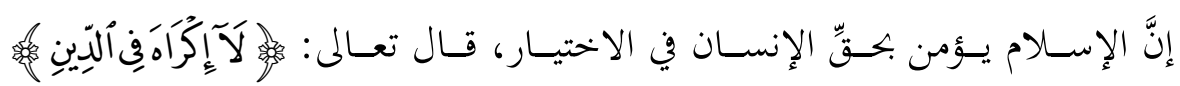

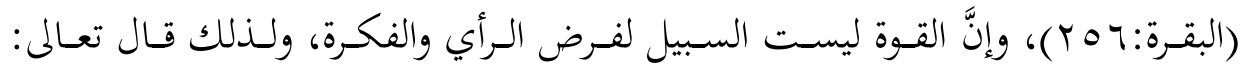

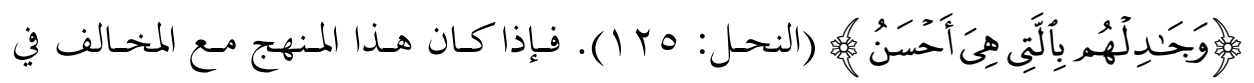

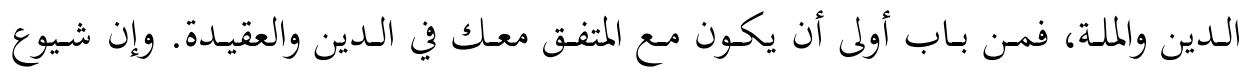

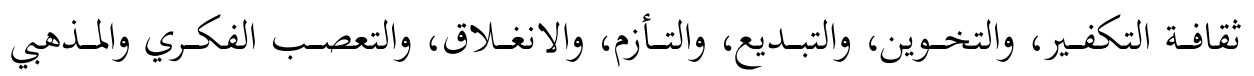

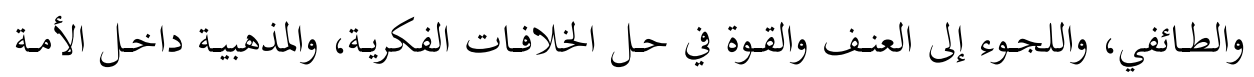

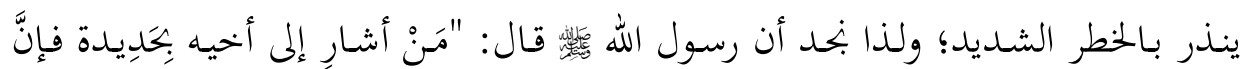

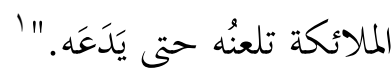

ولما كان الحوار بين مكونات الأمة المسلمة بمختلف مذاهبها العقدية أو الفقهية هو الأصل، والأساس لأيّ حوار مع غيرها، وملا كان القصد من الحوار هو تقليل الاختلاف، مولاف

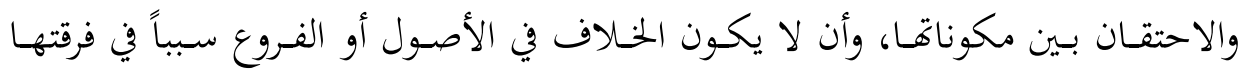

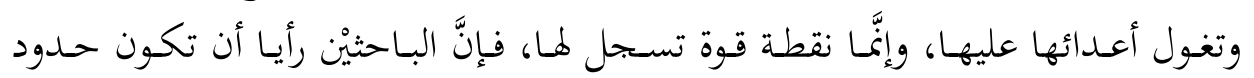

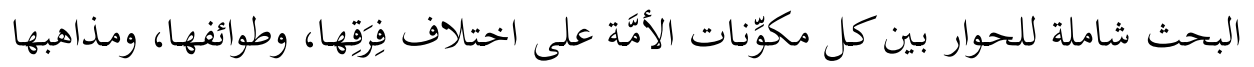

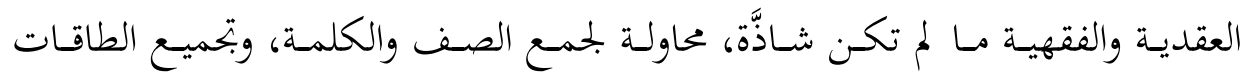

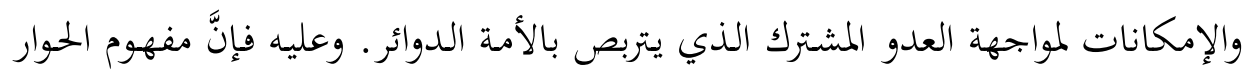

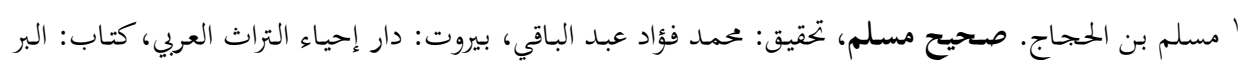

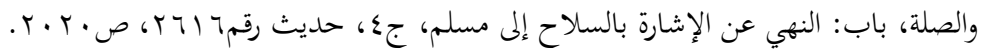




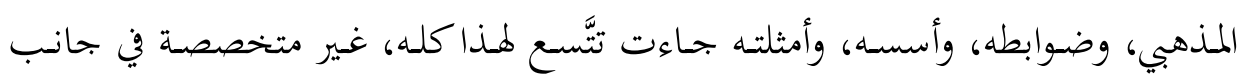

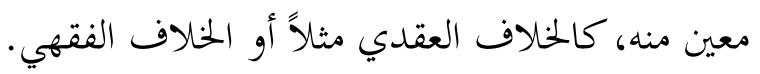
وإذا كان الحوار عموماً يمثِّل ضرورةً بشرية، وحتميةً إنسانيَّة، وسنَّةً ماضية من سنن الله -عز وجل - فإنَّ الحوار المذهبي بين المذاهب الإسلامية المختلفة، يمثّلو حتمية إسلامية لا بدّ من التعاطي معها بما يحقِّق للأمة ما تصبو إليه من منعة، ورفعة، وقدرة على إيصال

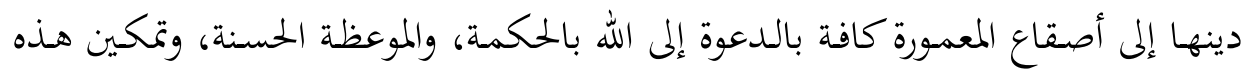

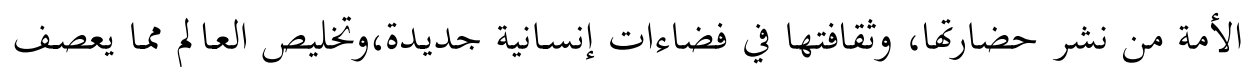

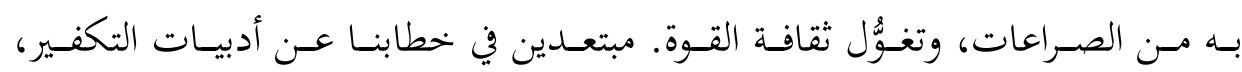

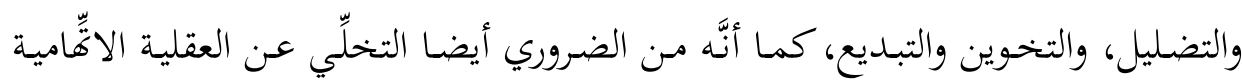

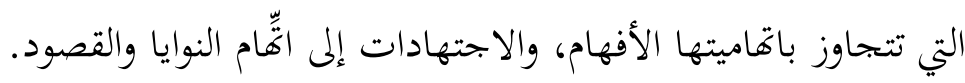

تحاول هذه الدراسة الإجابة عن بحموعة من الأسئلة من أهمها: ما هو مفهوم الحوار

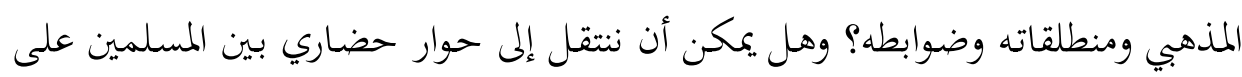

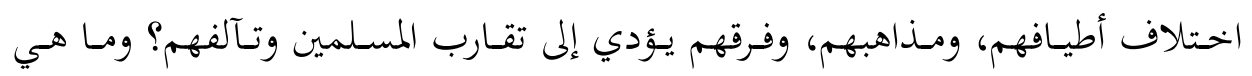

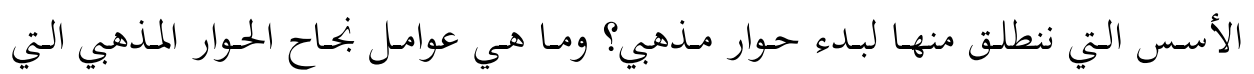
تجعله يؤتي تماره؟

1 ـ مفهوم الحوار لغة واصطلاحاً:

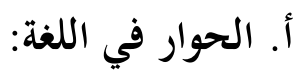
إذا يَمَّمنـا وجوهَنـا شَطْرَ معاجم اللغة محاولين معرفة المعاني، والدلالات اللغوية لهذه المادة في جذرها الثلاثي (حور)، فسرعان ما تطالعنا هذه المعاجم بمعان متعددة متداخلة، نغتار منها ما له علاقة بدراستنا، وهي: 


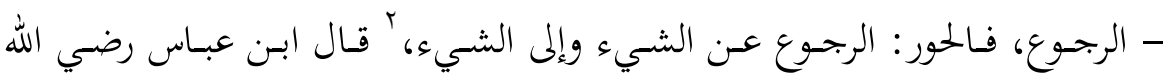

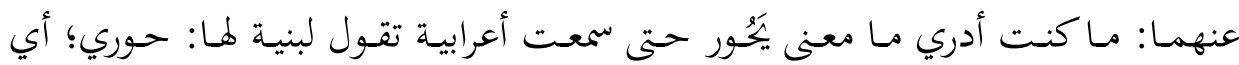

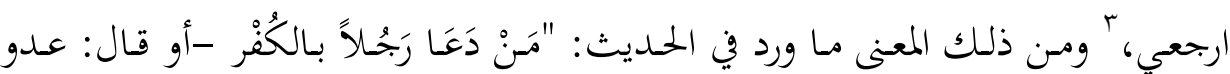

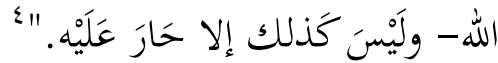

- المراجعــة في الكـلام والجـواب والـردّ فيقـال: يتحــاورون؛ أي يتراجعـون الكـلام.

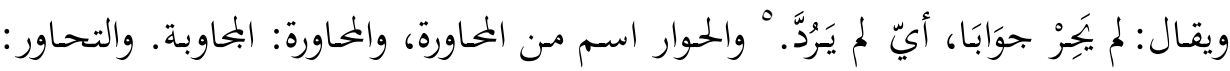

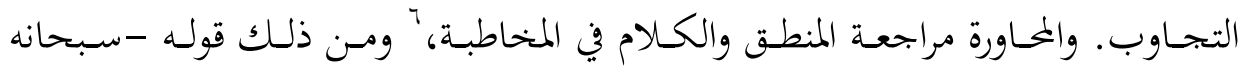

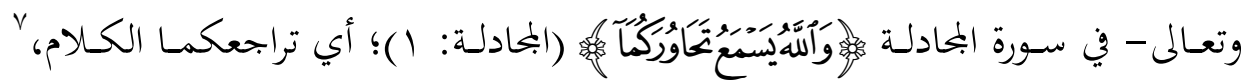

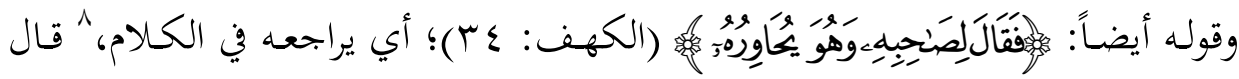
الراغب الأصهفاني: الحوار: المرادة في الكلام.

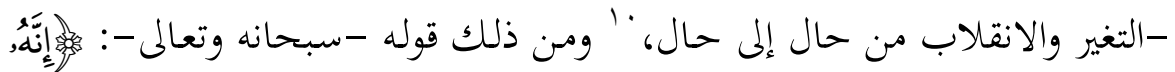

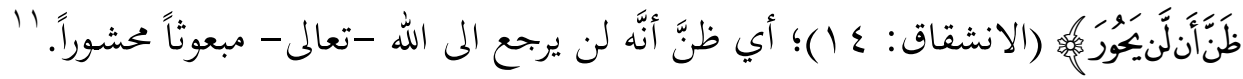

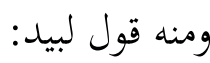

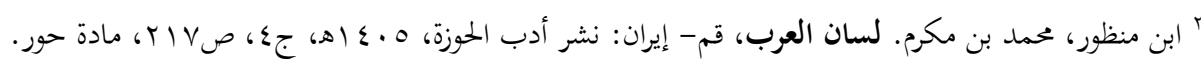

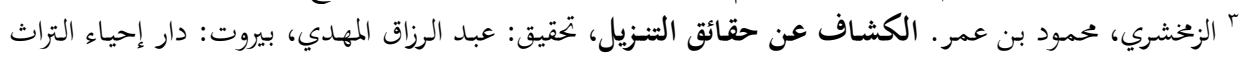

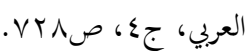

" ابن الحجاج، صحيح مسلم، مرجع سابق، كتاب: الإيمان، باب: حال إيمان من رغب عن أبيه، جا، حديث

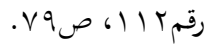

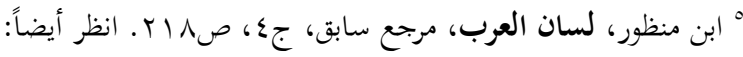

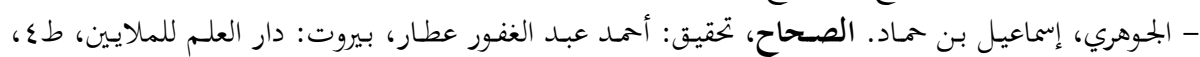

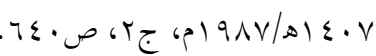

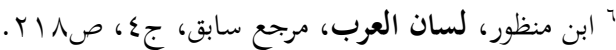

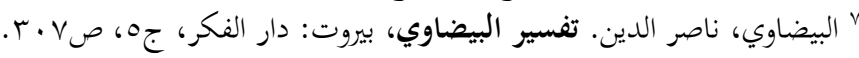

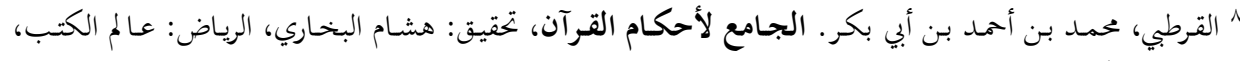

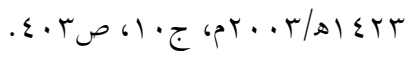
" الأصفهاني، الحسين بن عمد الراغب. المفردات في غريب القرآن، مكة المكرمة: مكتبة نزار الباز، و . . مم،

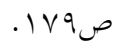

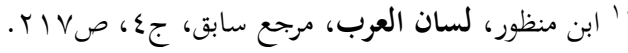

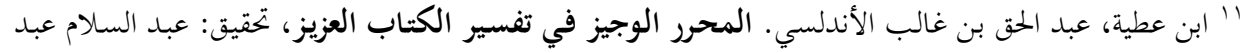

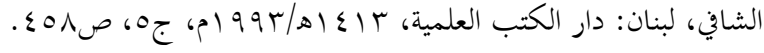




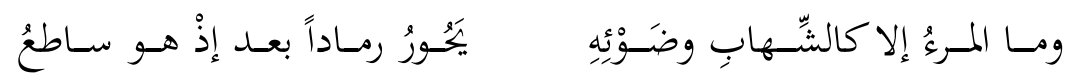

- المحور: الحديدة التي تدور عليها البكرة."' ومن هنا قالوا: محور الحوار؛ أي القضية الرئيسة التي يدور حولها.

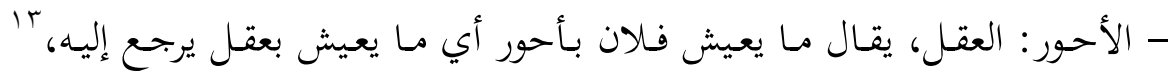
والحوار يمتاج إلى عقل حتى يتم بوجه صحيح.

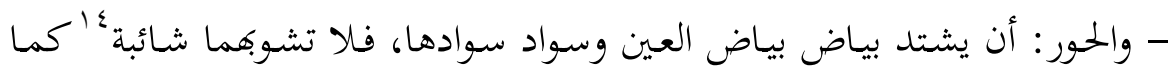

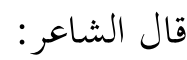

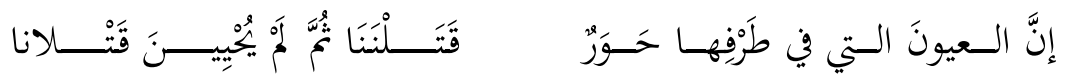

والحوار يؤدي إلى أن لا تشوب الأمورَ شائبة، بل تتميز الحقائق وتظهر. إنَّ كل المعاني اللغوي السابقة للحوار لها علاقة بالمعنى الاصطلاحي للحوار وتحدد مفهومه بشكل واضح. ب. الحوار اصطلاحاً: - (ب)

لقد تعددت عبارات الباحثين لدى تعريفهم الحوارَ من الناحية الاصطلاحية، ولعلَّ

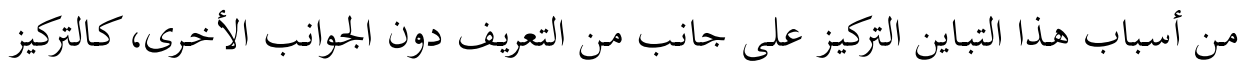

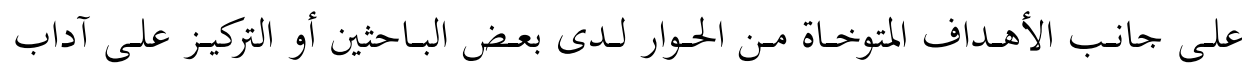
الحوار، وضوابطه لدى بعضهم الآخر، ولكن هذه التعريفات في النهاية تعريفات متقاربة.

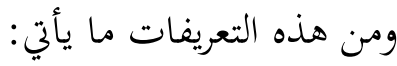

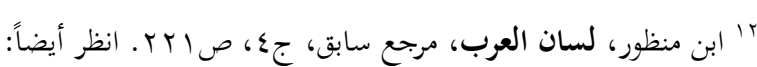

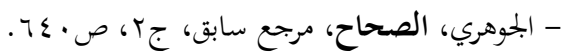

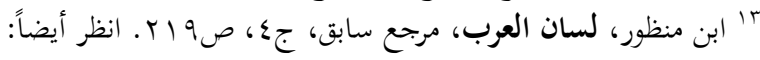

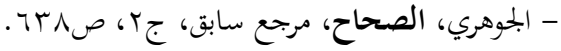

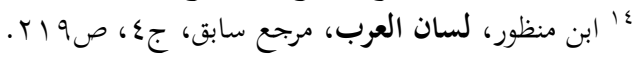




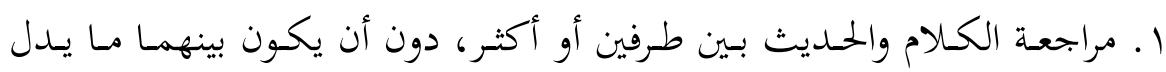

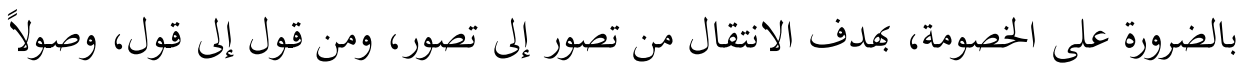
إلى التصورات الشاملة والمبادئ العليا. 10

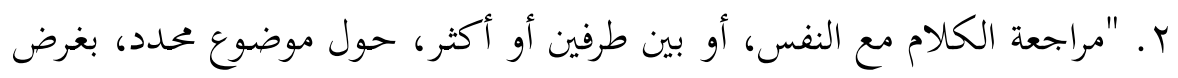

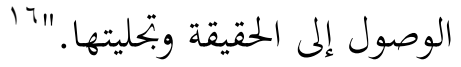

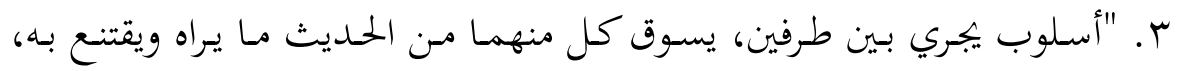

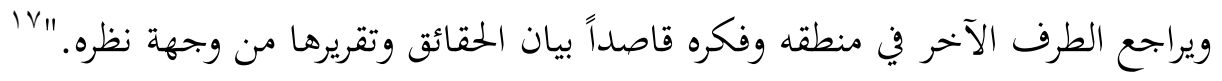

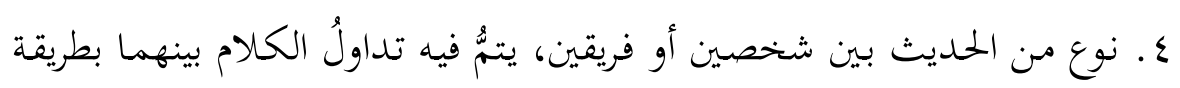

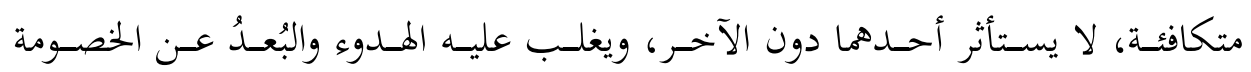

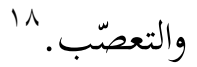

هـ "تبادل المتحاورين، الأفكار،، والحقائق والمعلومات والخببرات، التي تزيد من معرفة

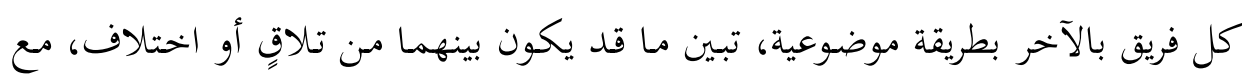

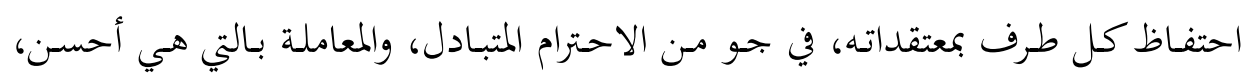

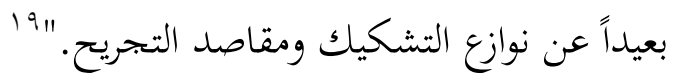

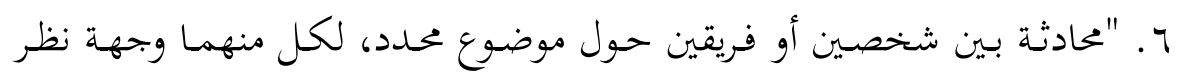

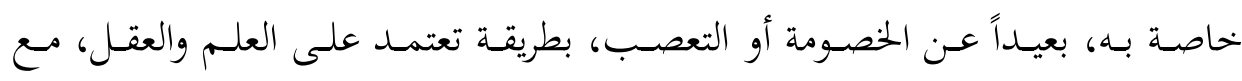

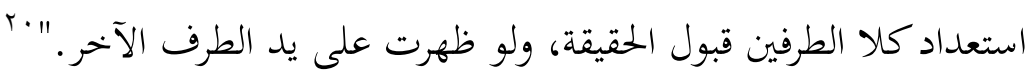

• 1 عامراني، عبد الجيد. مستقبل حوار الحضارات في ظل العولمة، الإمارات العربية المتحدة: ندوة الثقافة والعلوم،

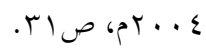
"17 المغامسي، خالد. الحوار: آدابه وتطبيقاته في التربية الإسلامية، السعودية: مركز الملك عبد العزيز للحوار الوطني،

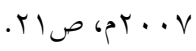

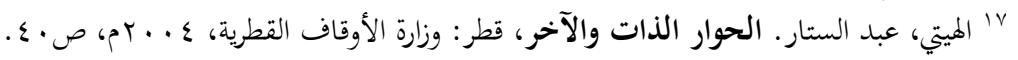

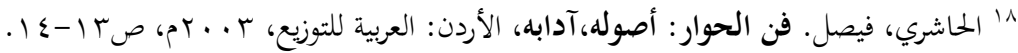

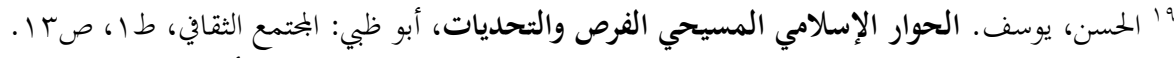

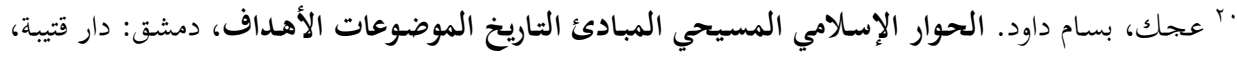


والعلاقـة بـين المعنى اللغـوي والاصطلاحي للحـوار يظهـر في أن الحـوار تراجـع بـين

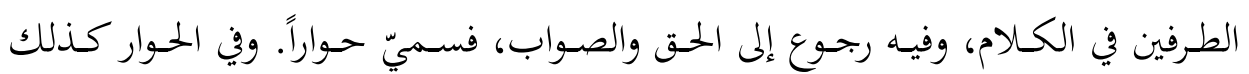

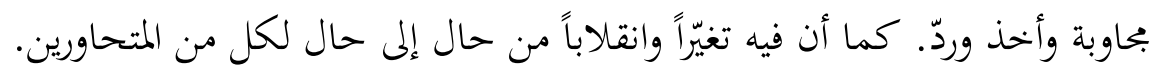

\section{Y ب. مفهوم المذهب لغة واصطلاحاً:}

أ. المذهب لفةً: مـن ذَهَبَ في الأرض مَرَّ ومضى، 'ب وجمعُه مذاهب. والمذهبب في

اللغة له عدة معان منها:

- القصد والطريقة، يقال: ذَهَبَ مَذْهَبَ فلان، قصد قصدَه وطريقتَه.

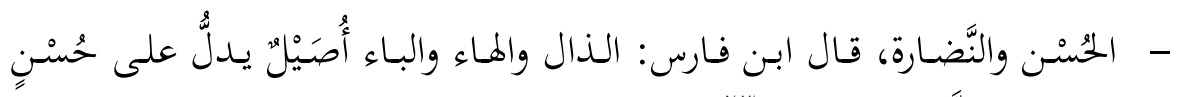
ونَضارة، من ذلك الذَّهبُ معروف.

ب. المذهب اصطلاحاً: هو المعتقد الذي يُذهب إليه، والطريقة، والأصل، يقال:

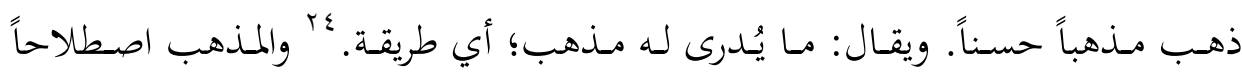

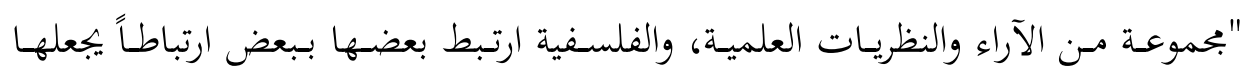

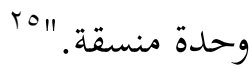

والمذهب في الاصطلاح الشرعي له تعريفات تكاد تكون متقاربة، منها:

مـا ذهـب إليه إمـام من الأئمة في الأحكام الاجتهادية أو العقدية. جاء في الفواكه

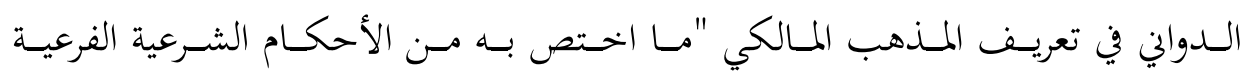

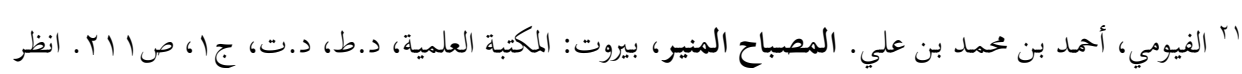
أيضاً:

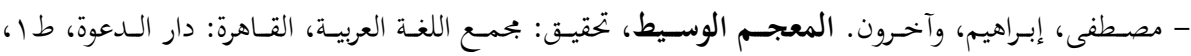

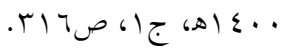

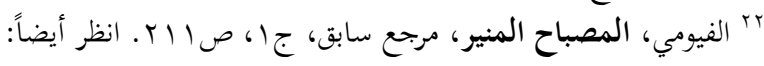

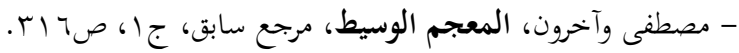

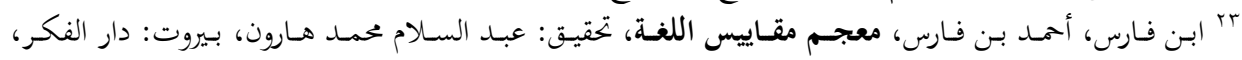

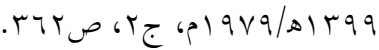

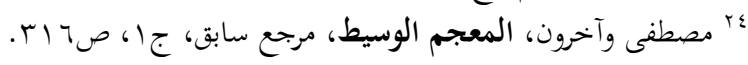

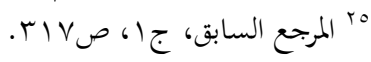




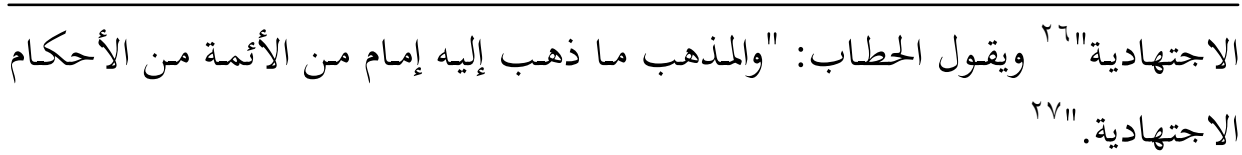

ويوضـح ذلك الدسـوقي بقوله: "مـذهب مالـك مـثلاً عبـارة عمـا ذهـب إليـه مـن

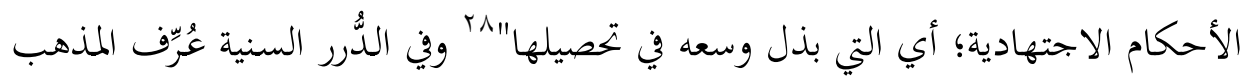
بأنه "ما ترجّح عند المجتهد في أيّة مسألة من المسائل بعد الاجتهاد، فصار له معتقداً، أو

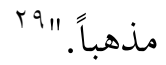

ويمكن مـن خهالال مـا سبق أن نُعِرِف المـذهب تعريفـاً يجمـع بـين المـذاهب الفقهيـة، والفكرية، والعقدية فنقول: بأن المذهب هو: المنهج الذي سلكه عالم بحتهد في الفقه أو أصول الدين، أدّى به إلى اختيار جملة من الأحكام في بحال علم الفروع أو الأصول. ومحا سبق أيضاً نرى أنَّ العلماء يرون أنَّ المذاهب فيما فهمه العلماء من النصوص، أو في المسـائل الاجتهاديـة. أمـا النصـوص الصسحيحة الصسيحة، التي لا معـارض لهـا، ولا ناستخ، ومسـائل الإجماع، فلا مـذاهب فيها، بـل هي أحكام نصسّ عليها الشـارع. يقول الدسوقي: "فالأحكام التي نص الشارع عليها في القرآن أو في السنة، لا تعد من مذهب أحد من المحتهدين." "r "ميقول الشنقيطي:

منــــه الــــي لمالــــك فيــــه اجتهـــــاد

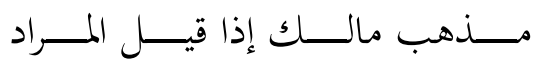
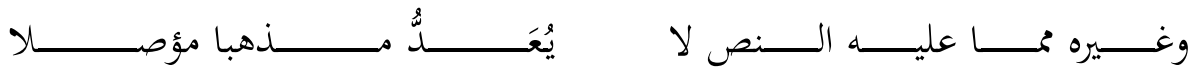

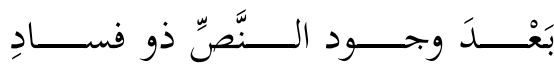

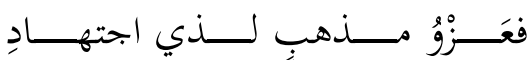

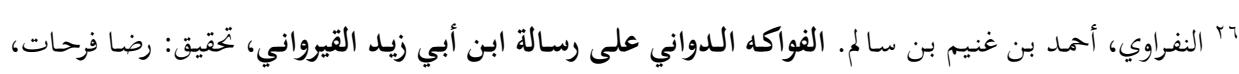

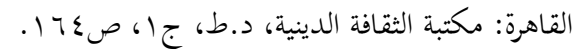

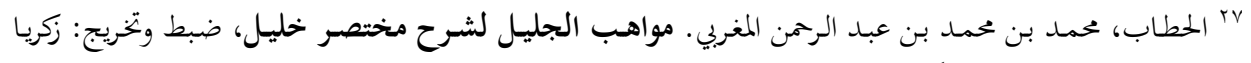

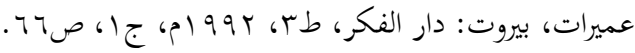

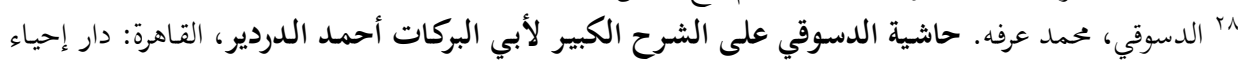

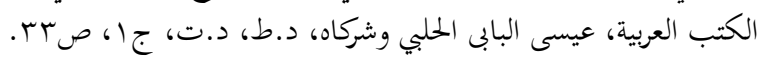

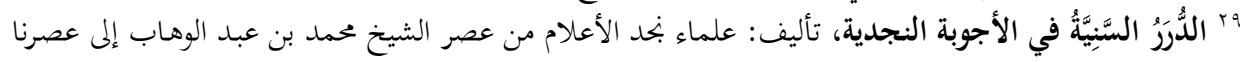

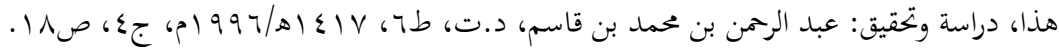

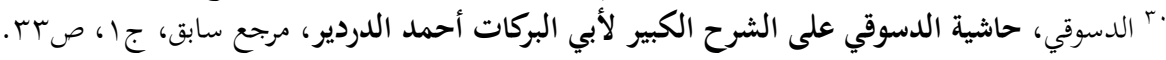




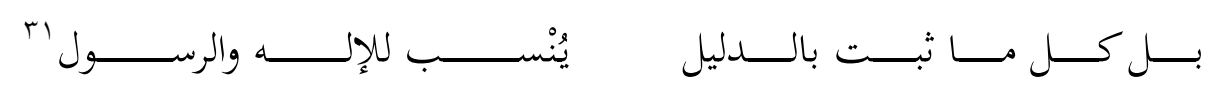

وجاء في الدرر السنية أنه لا يكاد يطلق إلا على ما فيه خلاف؛ إذ يقول: "... وأنَّ

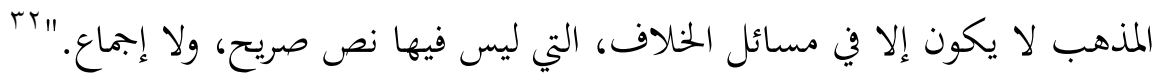

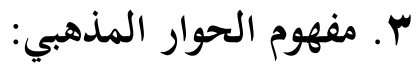

إنَّ مصطلح الحوار المذهبي مكون من الكلمتين: حوار، ومذهب، أمَّا الحوار المذهبي

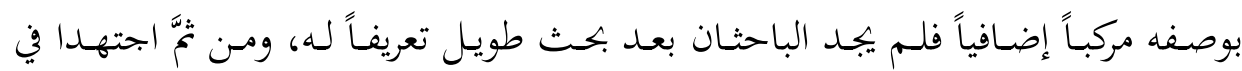

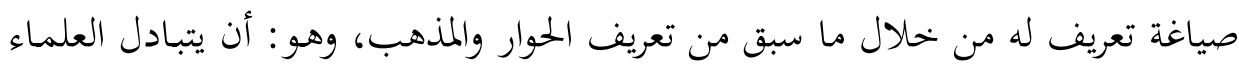

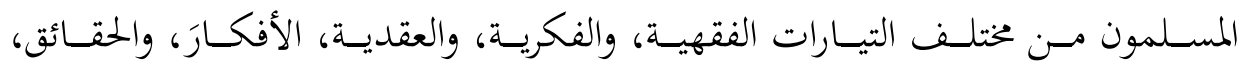

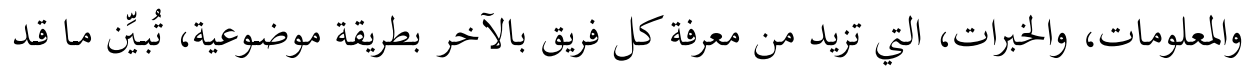

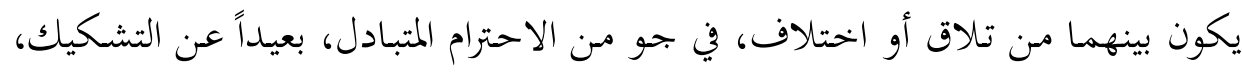
والتجريح للوصول إلى التقارب والتعايش والوحدة.

\section{ع. المصطلحات ذات الصلة}

ثمّة بحموعة من المصطلحات ذات الصلة بمفهوم الحوار منها:

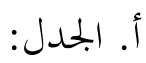

جدلته؛ أي رميته وصرعته، والجحدل: اللَّدَدُ في الخصومة والقدرة عليها، ورجل جحَدل إذا كان أقوى في الخصام. ويقال: جادلت الرجل فجدلته جدلاً؛ أي غلبته. وجادله؛ أي خاصمه. والاسم الجحل، وهو شدة الخصومة. والجحل: : مقابلة الحجة بالحجة، والمحادلة:

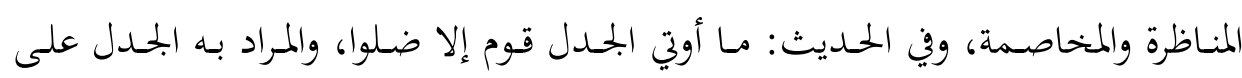

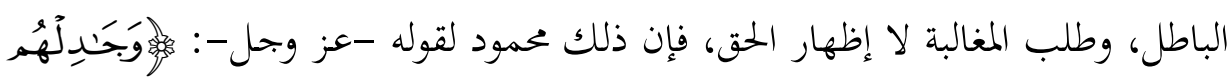

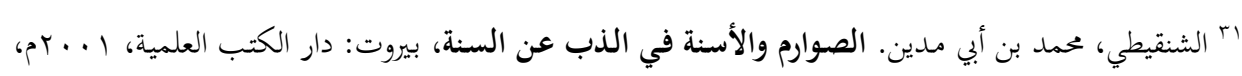

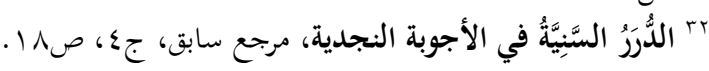




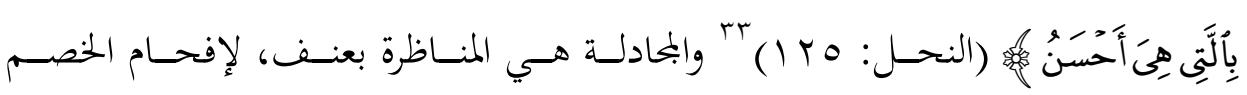
وإسكاته.

والمحادلة والجحدل اصطلاحاً هو: "معرفة القواعد من الحدود، والآداب في الاستدلال التي يتوصل بها إلى حفظ رأي، وهدمه سواء كان ذلك الرأي من الفقه أو غيره."

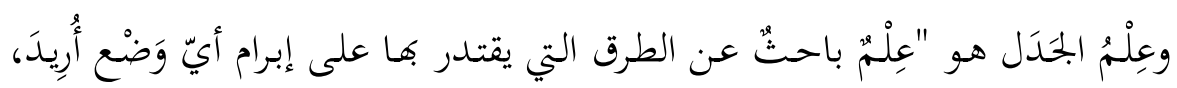

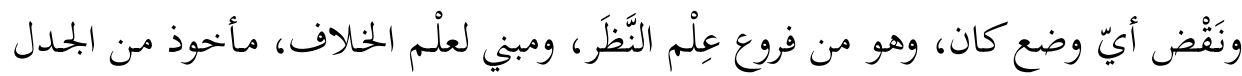

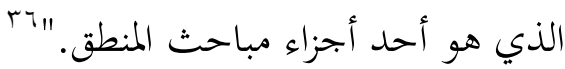

ومن خحلال ما سبق يتبين لنا أنَّ الجحدل يختلف عن الحوار في طبيعته، وإن كان قد يشبهه في الصورة الظاهرية؛ إذ إن الجدل في الغالب أمر غير محمود؛ لأنه ينبئ عن الصراع

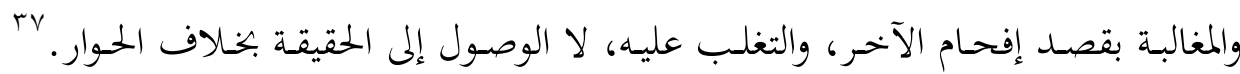
ولكن إن كان بقصد الوصول إلى الحق، والتزم بالضوابط الشرعية فهو أمر محمود.

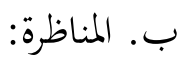

من النَّكرَ وهو حِسُّ العَيْن في الأصل، ويطلق على نظر القلب والفكر، وإذا قلت:

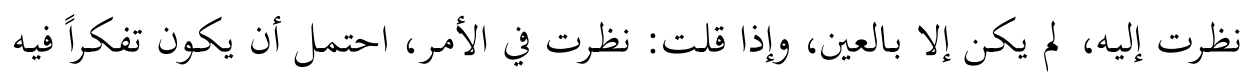

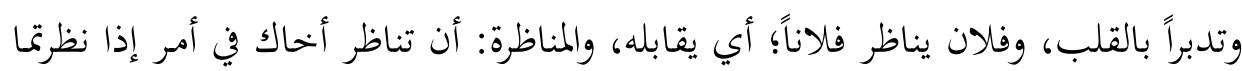

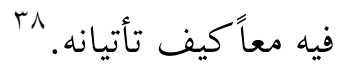
والمناظرة اصطلاحاً: هي إقامة الدليل على ما يخالف حجة الخصم.

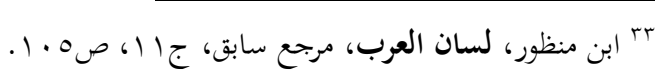

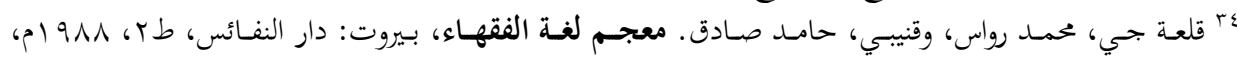

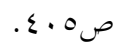

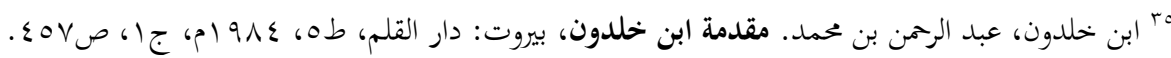

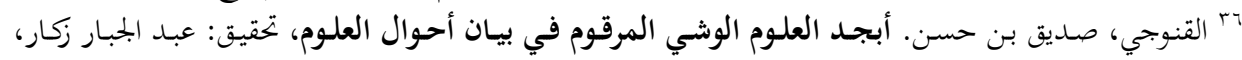

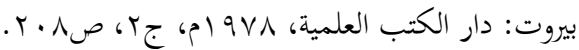

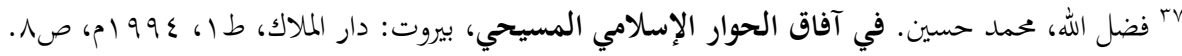

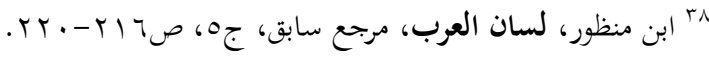

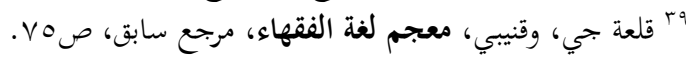




\section{ثانياً: منطلقات الحوار المذهبي}

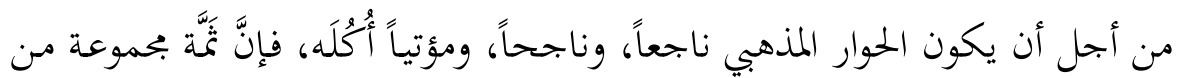

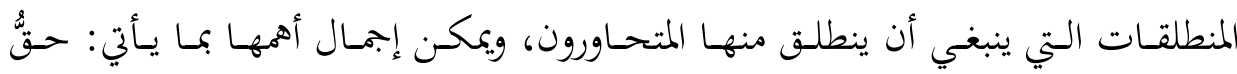
الإنسان في الاختيار دون إكراه أو إجبار. ووحدة الأمة الإسلامية. ومشروعية الخلاف. والتسامح المذهبي. والحرية المذهبية.

\section{ا ـ حقُّ الإنسان في الاختيار دون إكراه أو إجبار:}

إنَّ مـن أوَّل منطلقـات الحـوار الإيمـان ابتـاءً بحريـة اختيـار الإنسـان، والاقتنـاع بـأنَّ

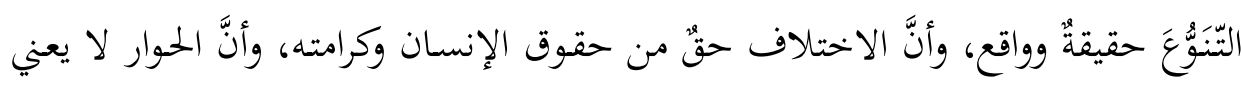
ولا يُطلب منه إلغاء التنوع ومصادرة حق الاختلاف وإكراه الناس على مـا لا يختارون. فأصحاب الرؤية الأحادية، الذين لا يمتلك تراثهم وقيمهم حق التنوع والاختلاف، غير مؤهلين ثقافياً وحضارياً لتقنية الحوار. •؛ إنَّ الإسلام من أكثر المبادئ دعوة إلى حرية الاختيار، وعدم الإكراه. والنصوص في

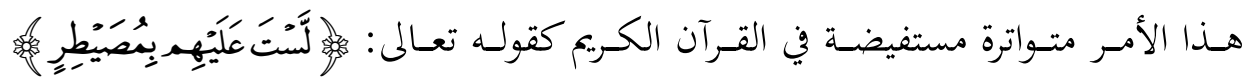

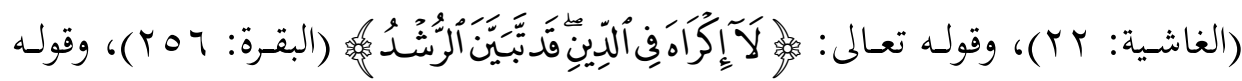

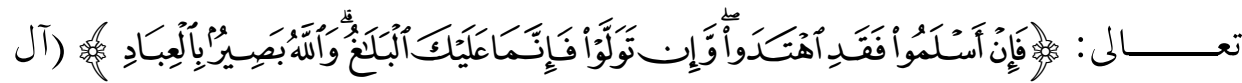

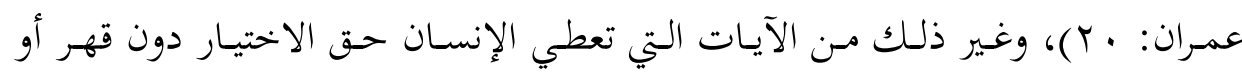
إجبار، محافظة على كرامته وحريته.

إنَّ هذا الأمسر يعطي الحوار أهميته وقيمته، ويجعل المحاور أكثر قناعة بجدلوى الحوار

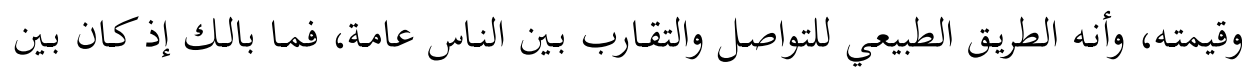

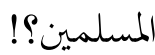

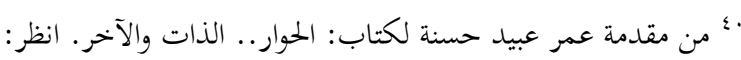

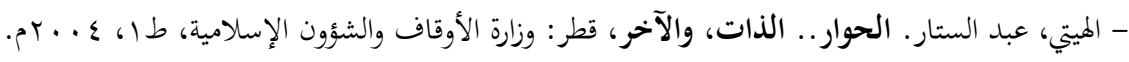




\section{Y. وحدة الأمة الإسلامية:}

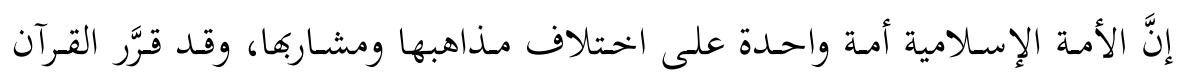

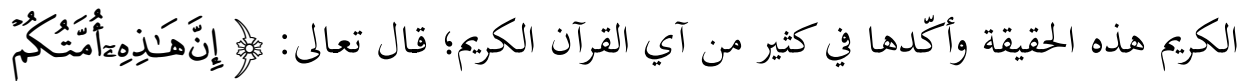

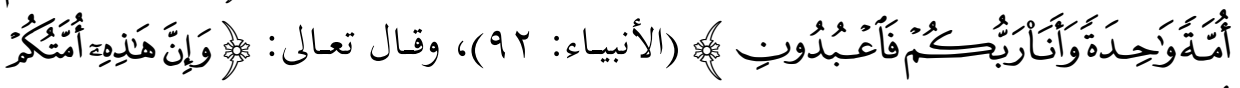

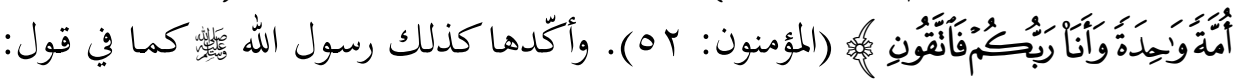

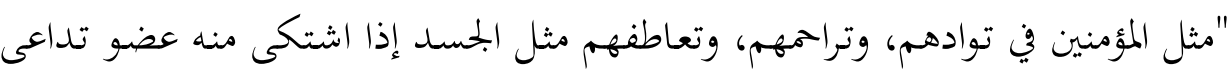

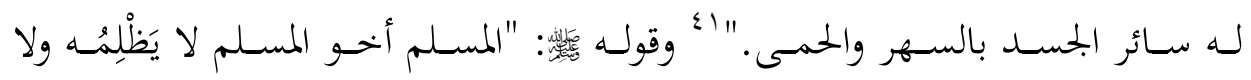
يُسنْلمُهـه.

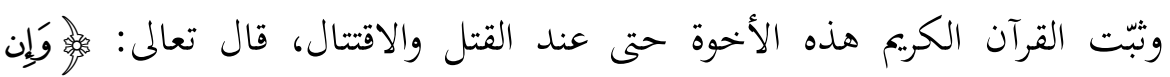

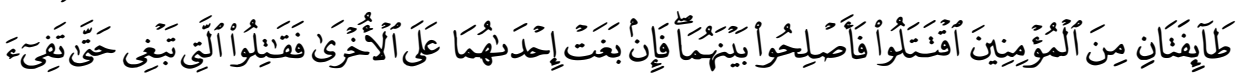

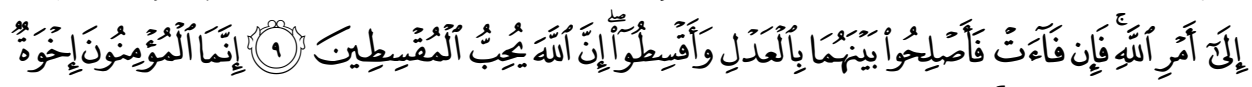

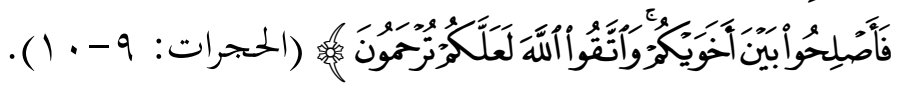

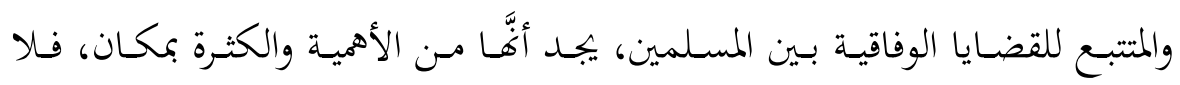

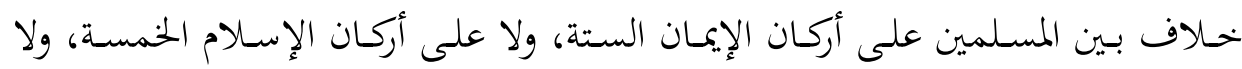

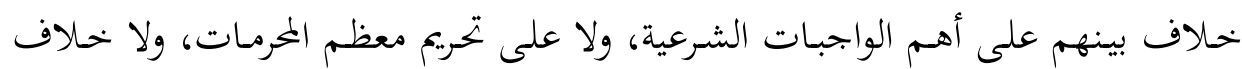

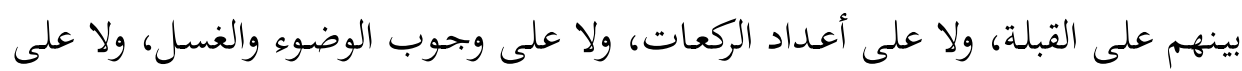

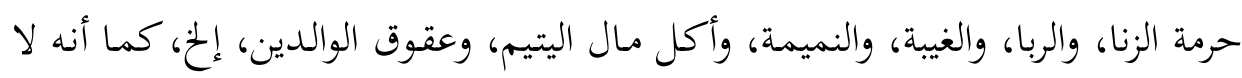

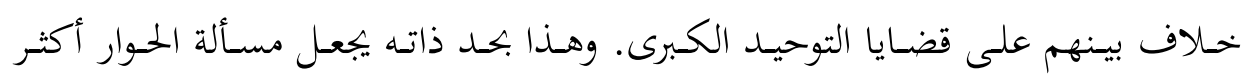
سهولة وإلحاحاً.

اء ابن الحجاج، صحيح مسلم، مرجع سابق، كتاب: البر والصلة، باب: تراحم المؤمنين وتعاطفهم، جع، حديث

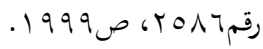

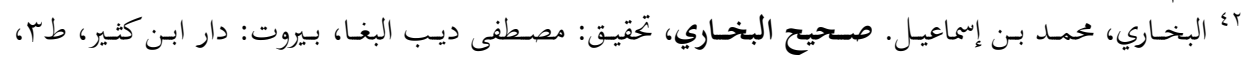

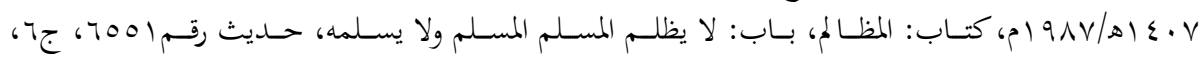

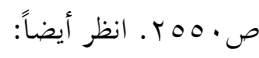
- ابن الحجاج، صحيح مسلم، مرجع سابق، كتاب: البر والصلة، باب: تحريم ظلم المسلم وخذله، جع، حديث إنه 


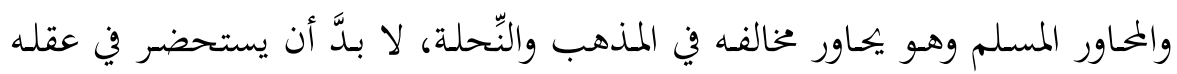

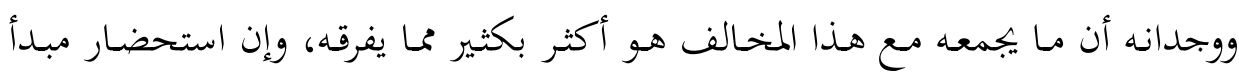

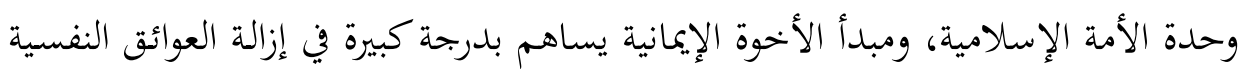
من طريق الحوار، ويجعل المحاور المسلم أكثر تقبلاً للآخر.

وكذلك تركيز المحاور المسلم على وحدة الأصول أمر في غاية الأهمية، ولذلك "فإنَّ

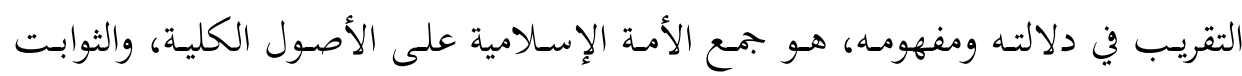

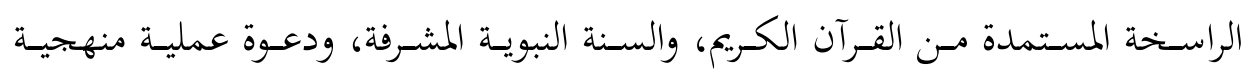

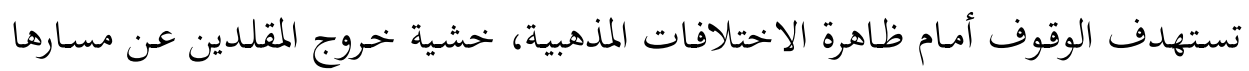

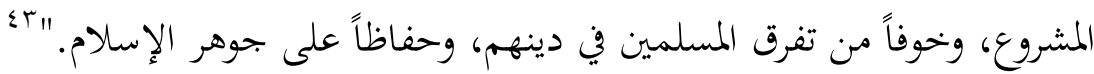

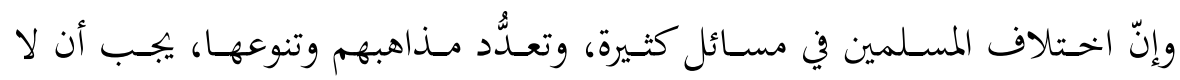

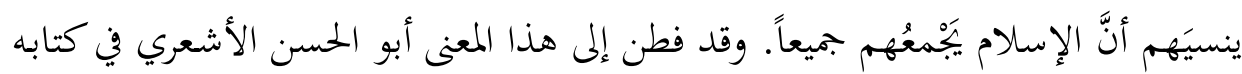

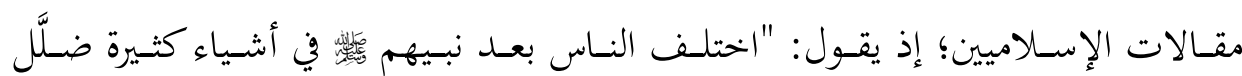

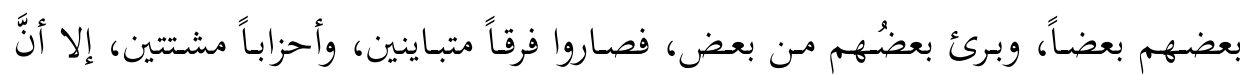

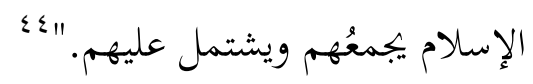

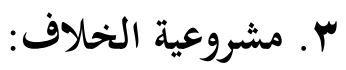

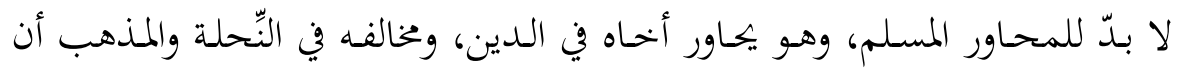

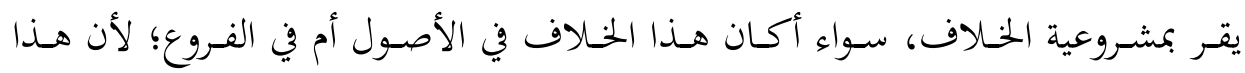

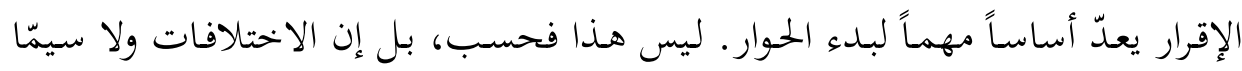

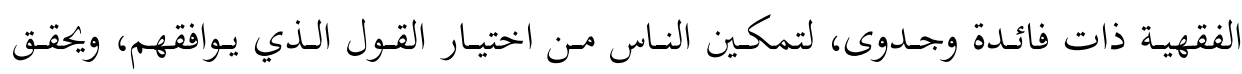

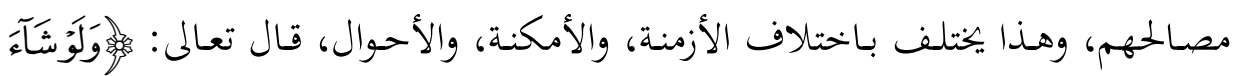

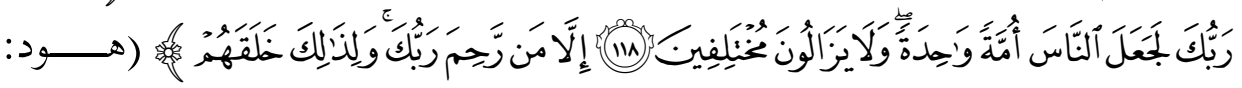

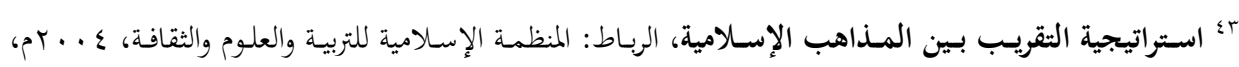

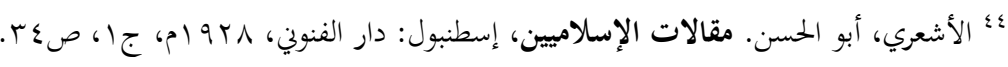


11 | -9 1 1)، وفي ضوء ذلك فمن الطبيعي أن تتنوع الاجتهادات، والأفكار، والمذاهب

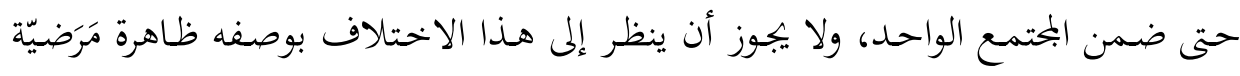

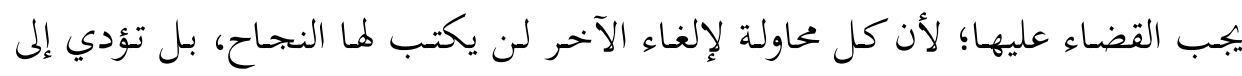

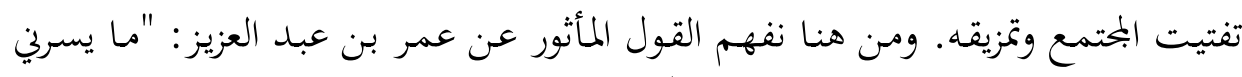

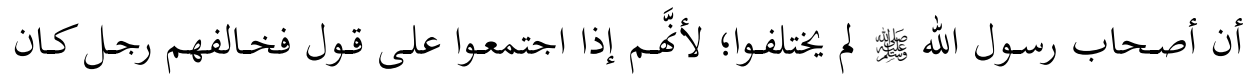

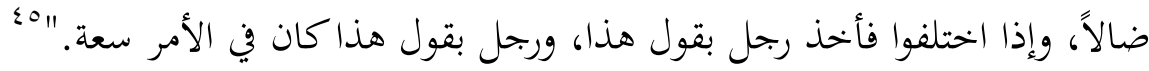
فإذا كان الإسلام قد جعل الاجتهاد فرضاً على الأمة، وجعل كلاً مـ المحتهديْن:

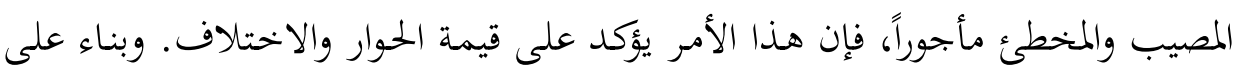
هذا الفهم الراقي تعددت المذاهب الفقهية، وظهرت المدارس الاجتهادية، وتشعبت آراء العلماء في مختلف المسائل الفروعية والأصولية.

وإنَّ الناظر يرى بعض أتباع المذاهب الإسلامية لا يقرون بمشروعية الاختلاف، بل

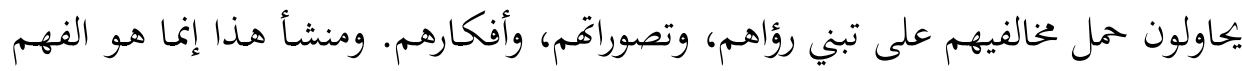

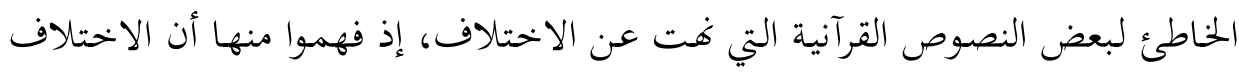

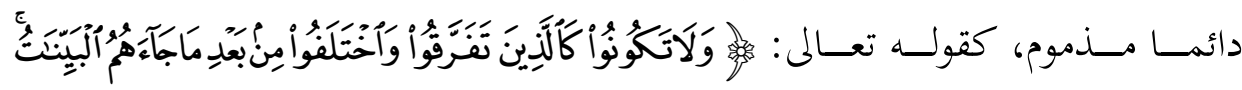

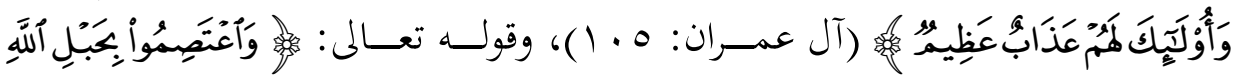

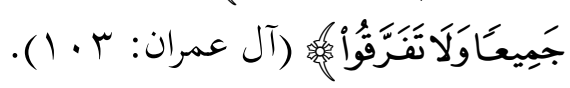

وقد عالج الفقهاء هذا الفهم الخاطئ من خلال التفرقة بين الاختلاف المذموم، وغير المذموم، قال القرطبي في تفسيره الآية السابقة: "وليس فيه دليل على تحريم الاختلاف في في فئ

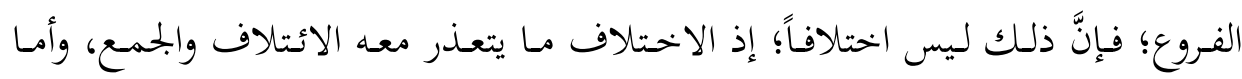

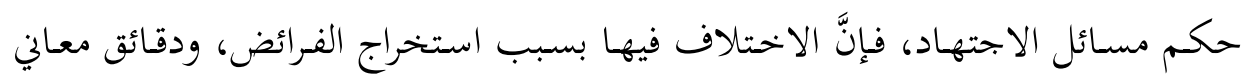

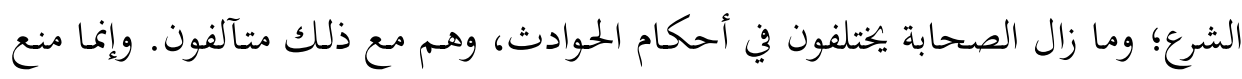

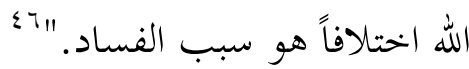

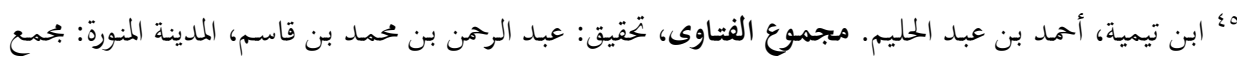

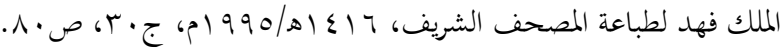

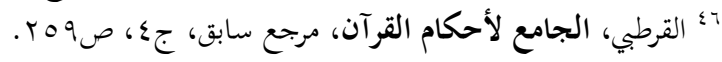


هذا الفهم الذي أورده القرطبي في تفسير الآية، ينطبق على كل النصوص الشرعية

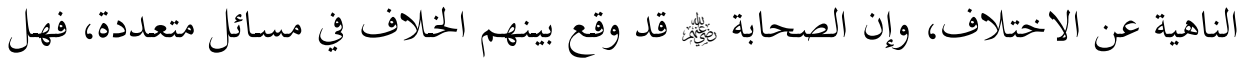

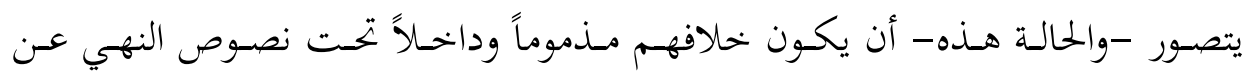

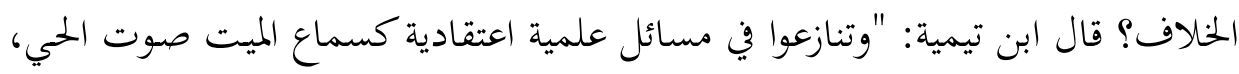

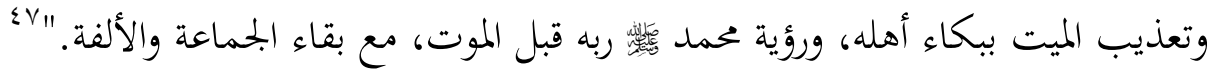
ويزْخَرُ تاريخُنا بصور الاختلاف الراقية، فقد اختلف أبو بكر وابن عباس مع زيد ابن

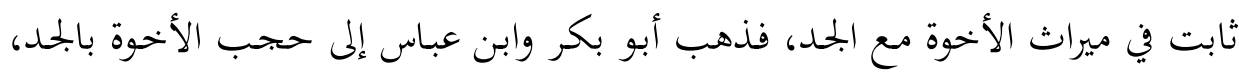

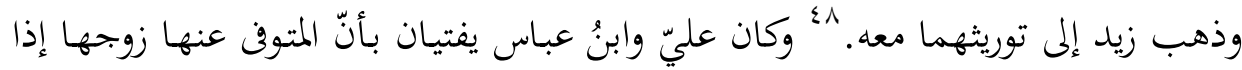

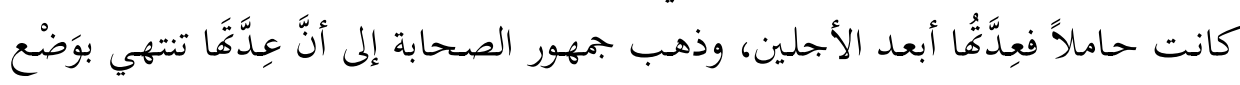
؛

واختلف المتهـدون في مسـائل لا تحصى، ولكننـا في هـذا المقـام نورد أمثلـة لمسـائل

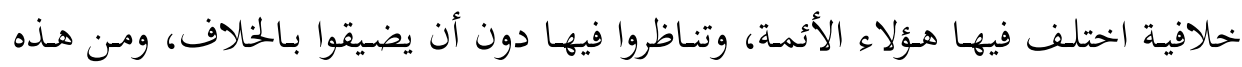
الأمثلة:

أ. التقى الأوزاعي بـأبي حنيفـة فقـال الأوزاعي: مـا بـالكم لا ترفعـون أيــيكم عنــ

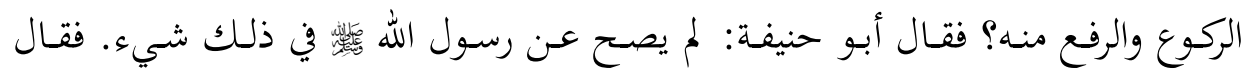

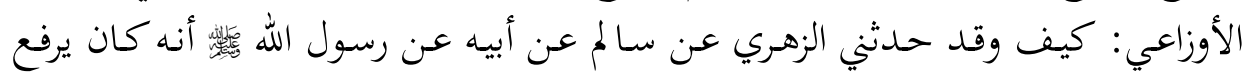

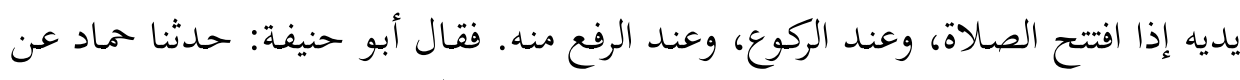

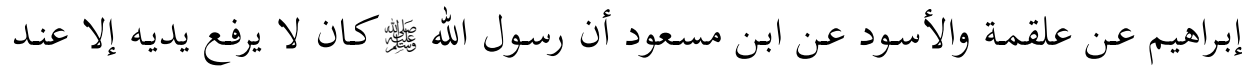

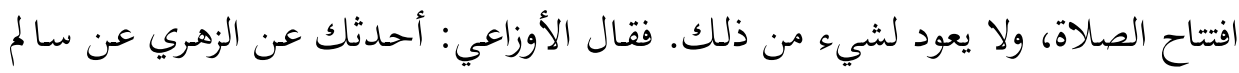

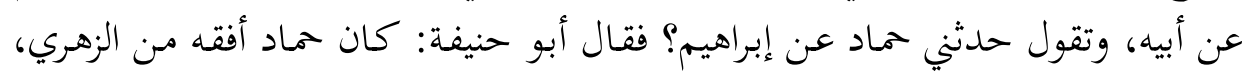

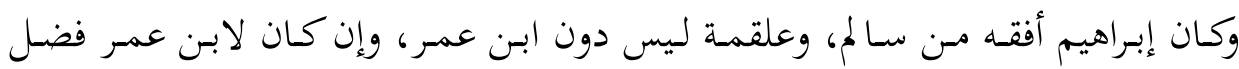

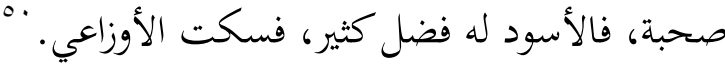

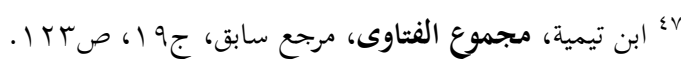

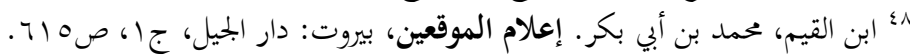

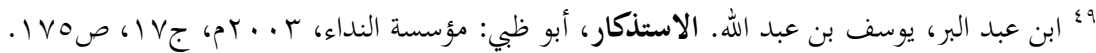

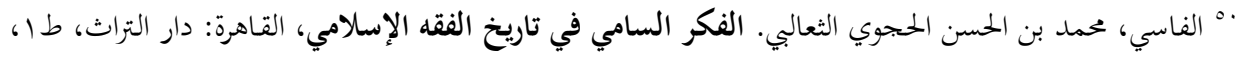




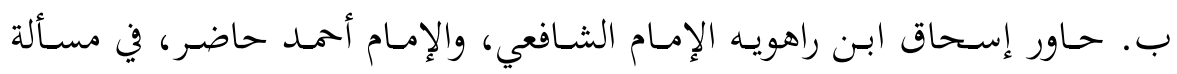

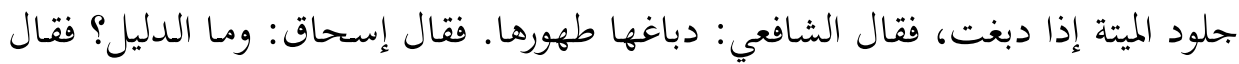

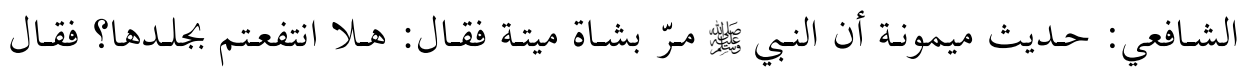

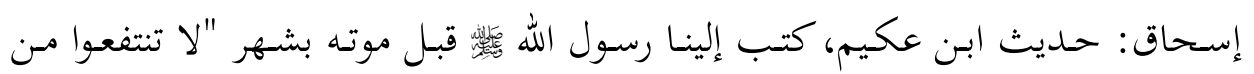

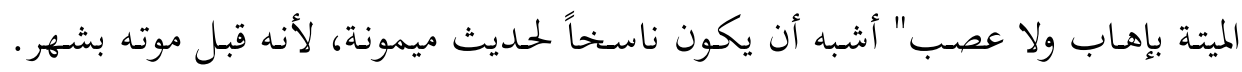

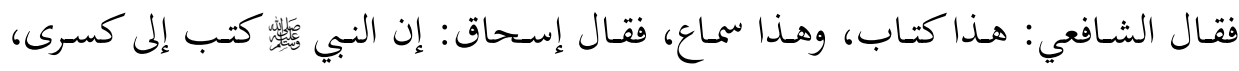

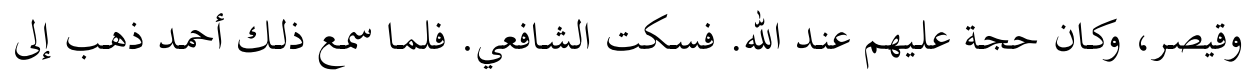

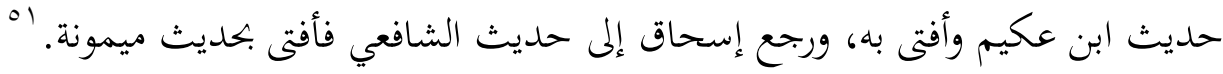

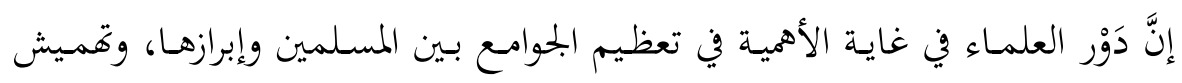

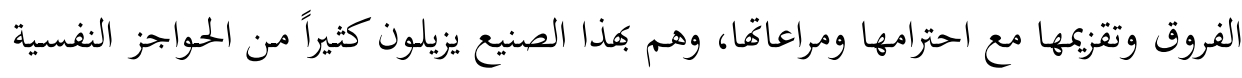

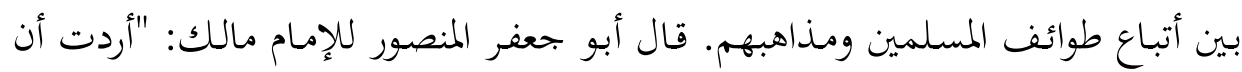

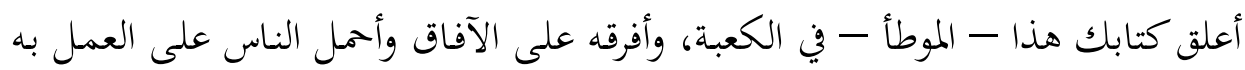

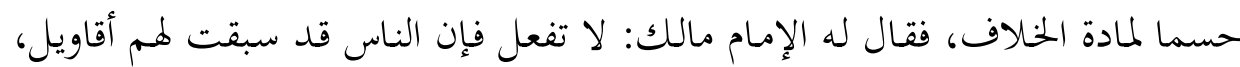

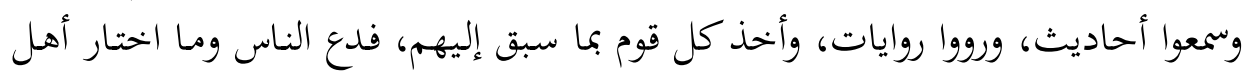

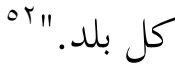

وذكر ابن تيمية "كان بين الحنبلية والأشعرية وحشة ومنافرة، فقال:كنت من أعناف أعظم

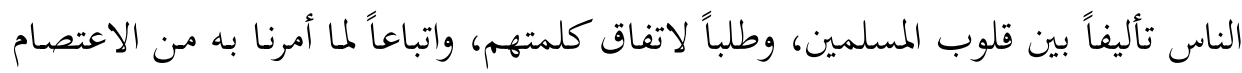

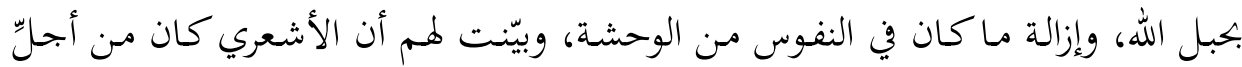

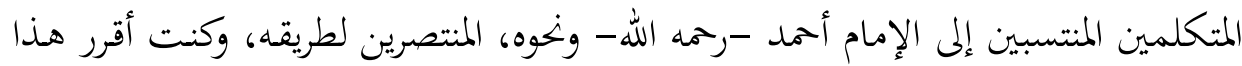

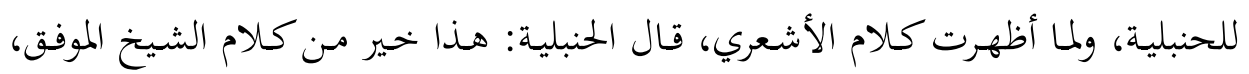

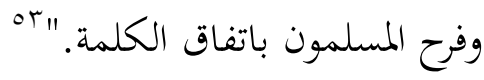

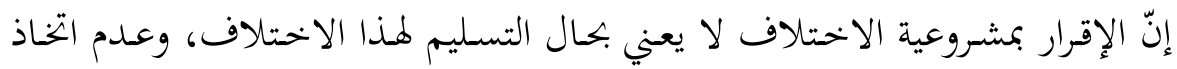

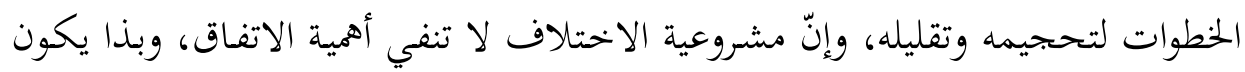

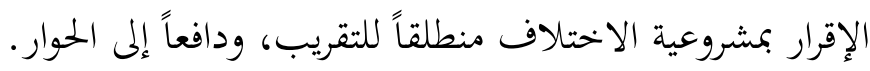

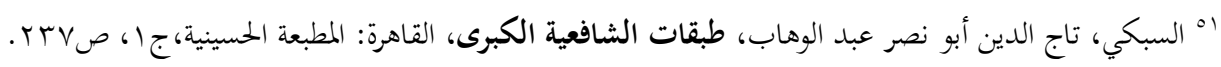

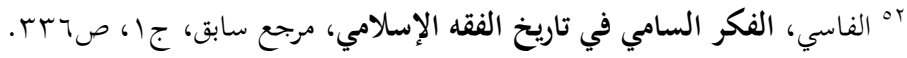

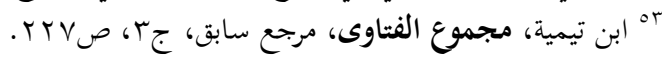




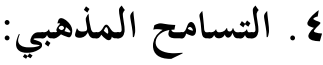

يتغذى التعصب المذهبي على الضيق بالخلاف، فالمذهبي المتعصب لا يرى مشروعية

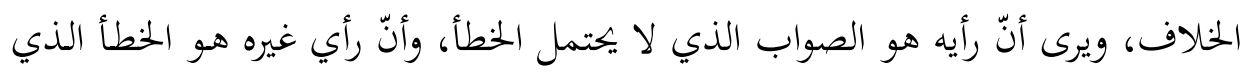

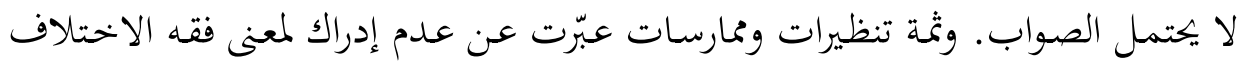

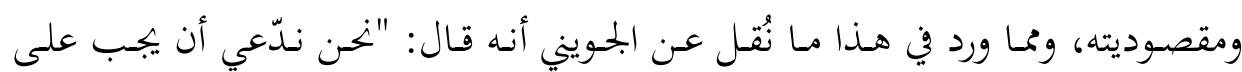

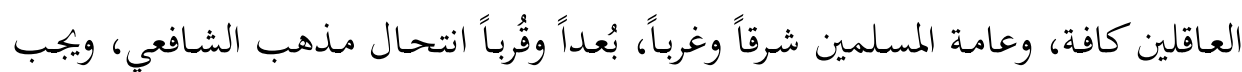

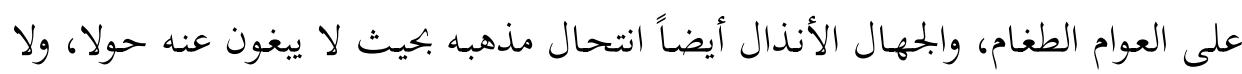

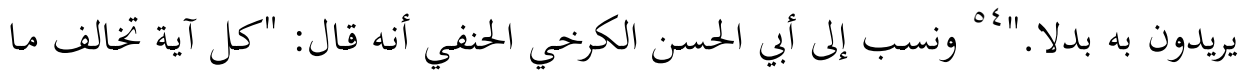

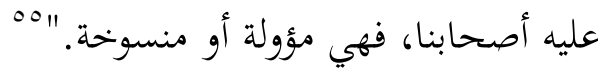

ويقول الصنعاني "وهكذا كل واحد يُعَظِّم إمَامَه، ويُرجِّح مذْهبَه، ويدعو إلى التقيّد

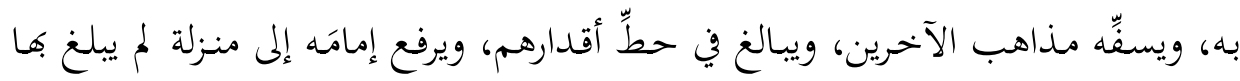

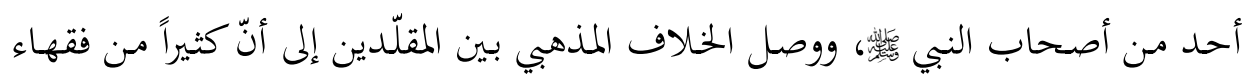

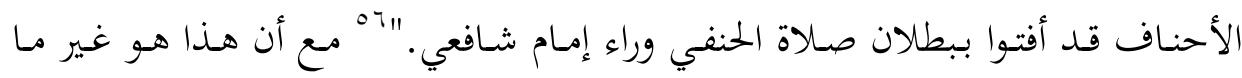
جرى عليه سلف هذه الأمة.

وتََّّة نماذج كثيرة تظهر لنا تسامح السلف الصالح فيما بينهم، ومن تلك الشواهد:

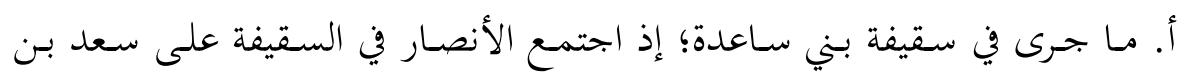

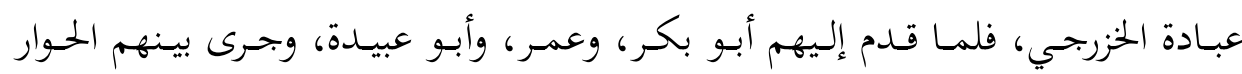

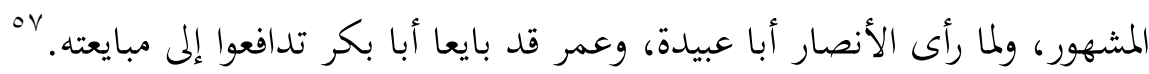

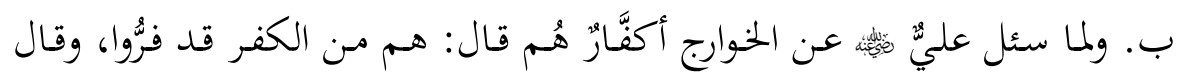

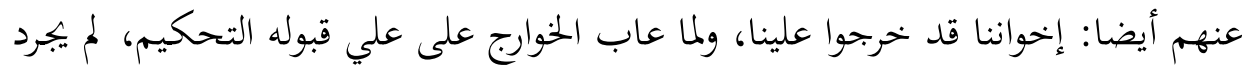

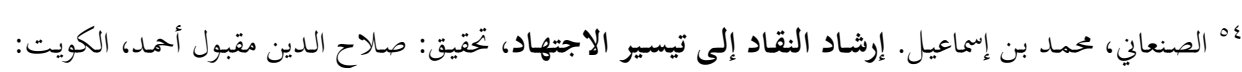

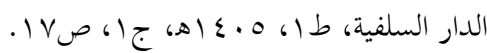

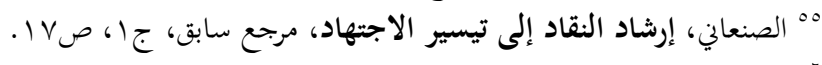

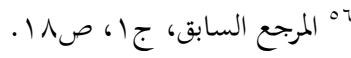

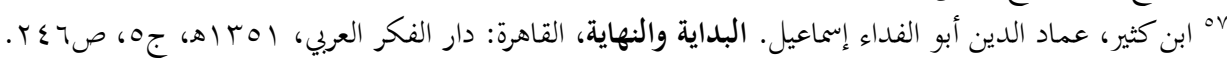


عليهم السيف، ولكنـه حـاورهم بالحجـة والبرهـان، وأرسـل إليهم ابـن عبـاس، وقـال لا لا

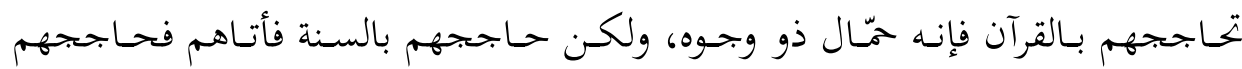
بالقرآن، وبالسنة فحجهم، فقيل: إهـم دخلوا في طاعته عن آخرهم، وقيل : بل دخل

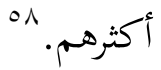

ت. وكان التسـامح مع المخـالف في المـذهب دَيْـَنَّ أئمسة المـذاهب، وبلغ التسـامح

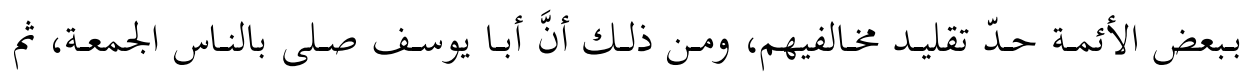

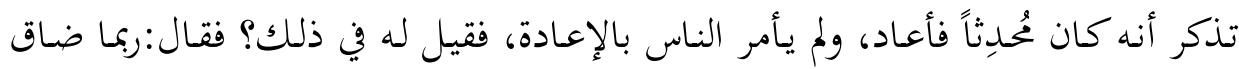

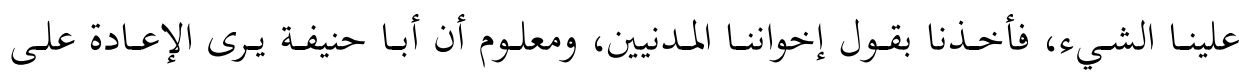

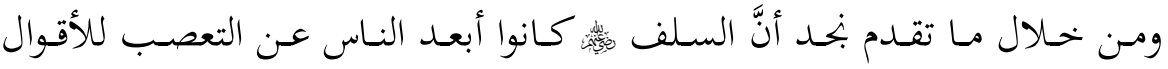
المفضية إلى التقاطع والتكفير، ويصور لنا يميى بن سعيد الأنصاري، وهو من كبار التابعين

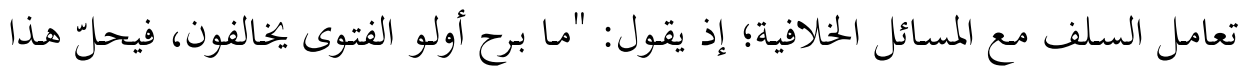

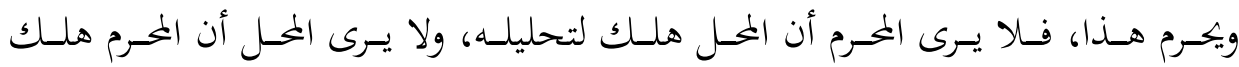
لتحريمه." لج وقال ابن قدامة المقدسي: "لا ينبغي لأحد أن ينكر على غيره العمل بمذهبها،

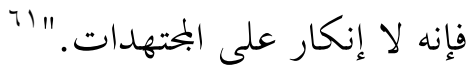

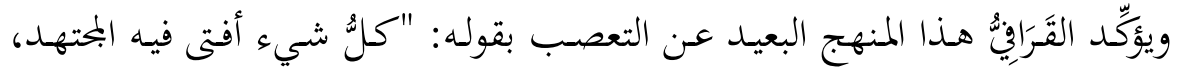

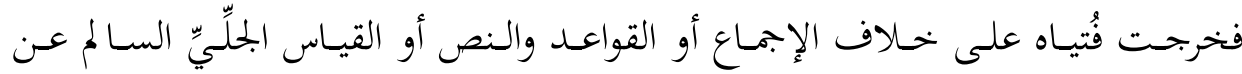
المعارض الراجح، لا يجوز لمقلده أن ينقله للناس، ولا يفتي به في دين الله تعالى، فالفُتيا

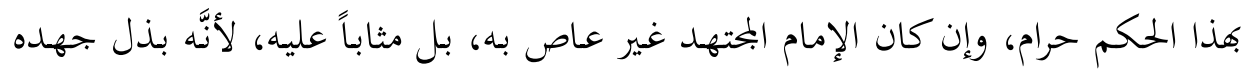

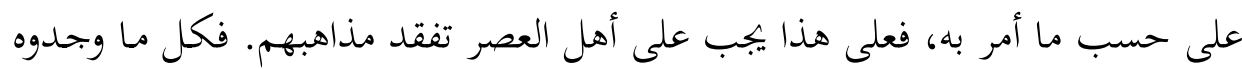

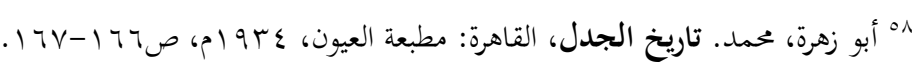

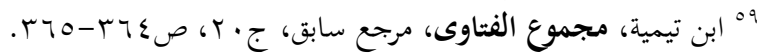

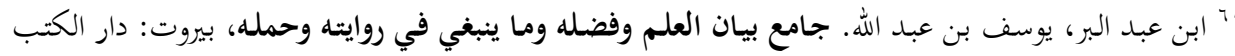

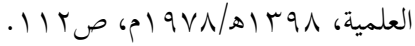

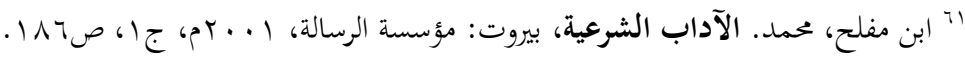




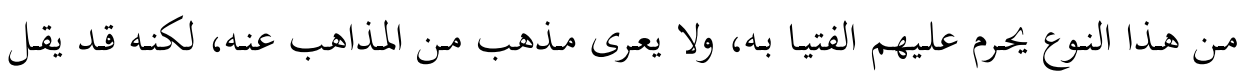

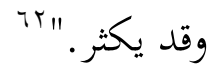

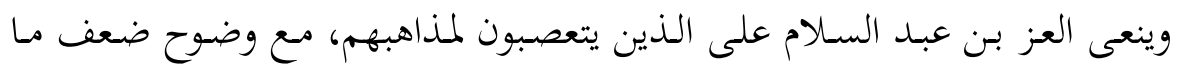

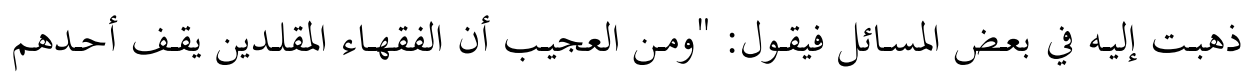

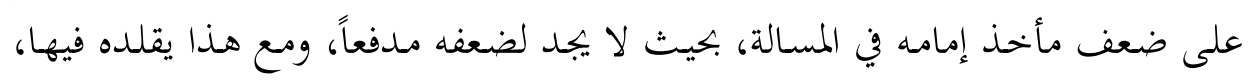

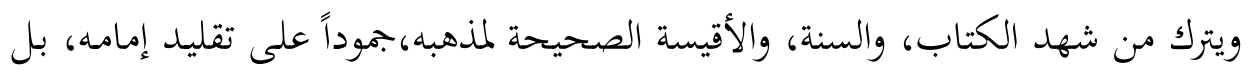

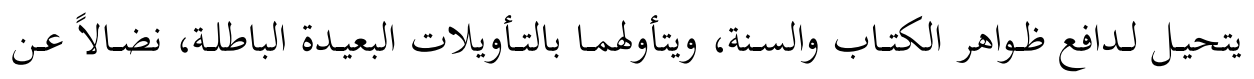

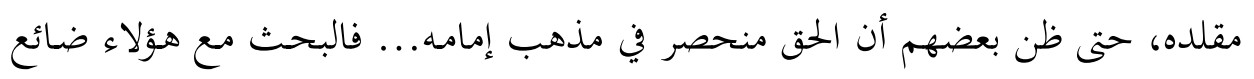

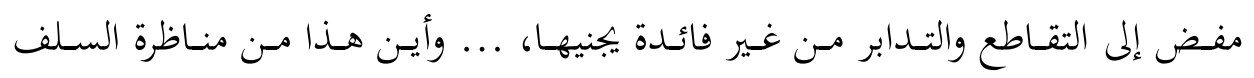

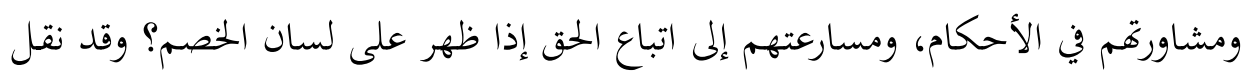

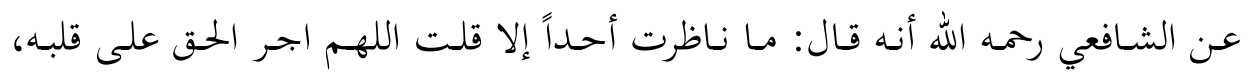

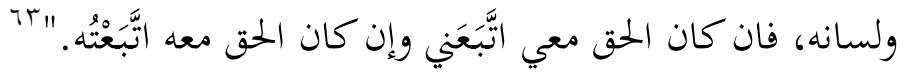

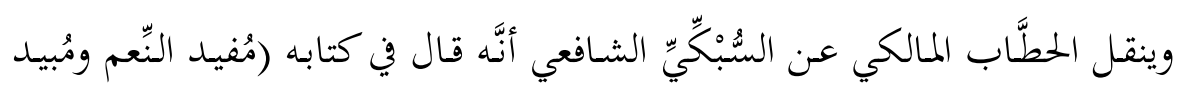

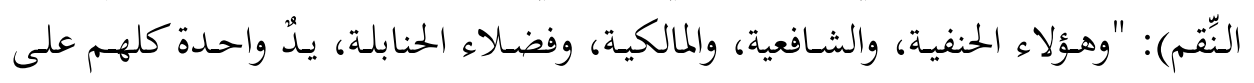

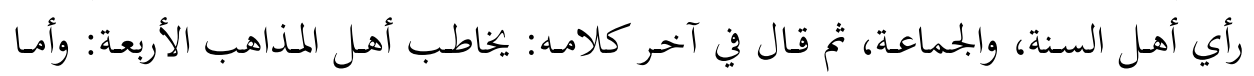

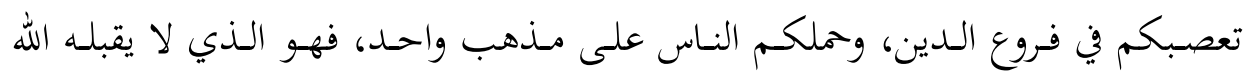

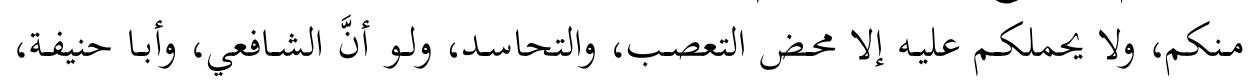

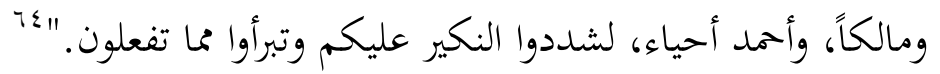

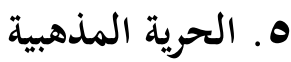

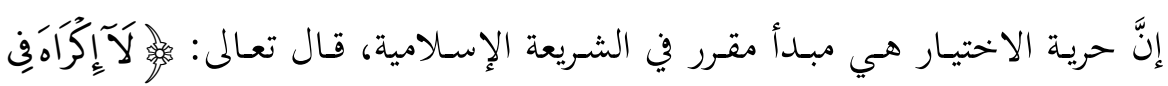

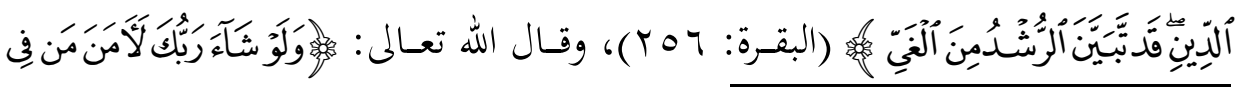

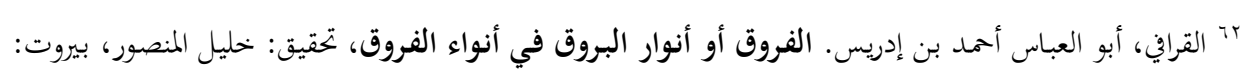

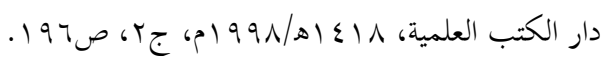
"Tiا ابن عبد السلام، العز . قواعد الأحكام في مصالح الأنام، تحقيق: حممود الشنقيطي، بيروت: دار الكتب العلمية،

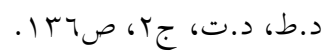
"' الحطاب، مواهب الجليل شرح مختصر خليل، مرجع سابق، جا، صه ب. 


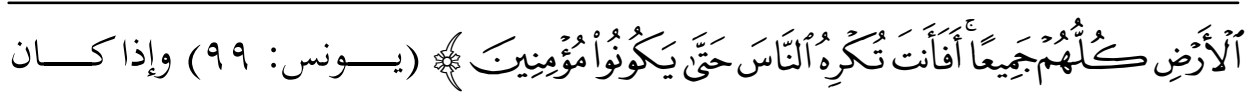
القرآن لا يقر مبدأ الإكراه على الدين، فمن باب أولى لا يقر مبدأ الإكراه على المذهبب

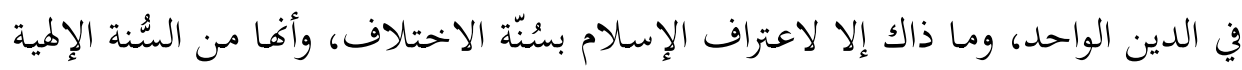
الجارية.

ومن صور الإكراه على المذهب عند بعض المسلمين، وهو ما دفعهم إلى التباغض،

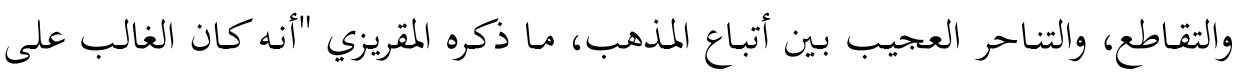

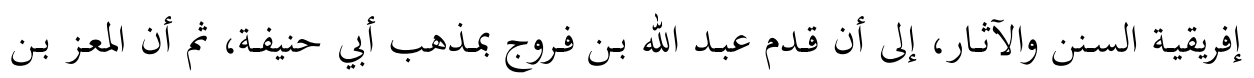

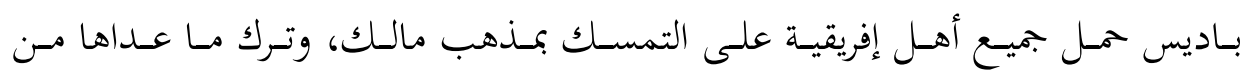
المذاهب، فرجع أهل إفريقية وأهل الأندلس كلهم إلى مذهب مالك إلى اليوم، رغبةً فيما عند السلطان، وحرصاً على طلب الدنيا، فكان القضاء والإفتـاء في جميع تلك المـدن،

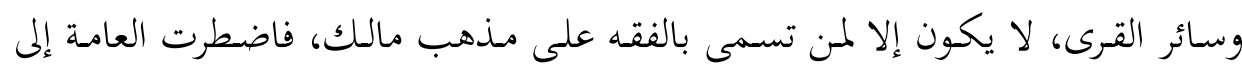

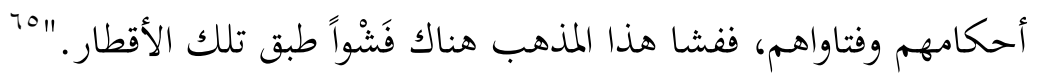
وذكر الحافظ ابن كثير أنَّ الملك الأفضل ابن صلاح الدين (توفي 990 هـ)، كان قد

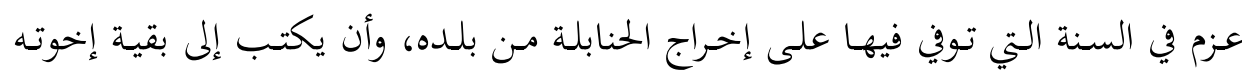

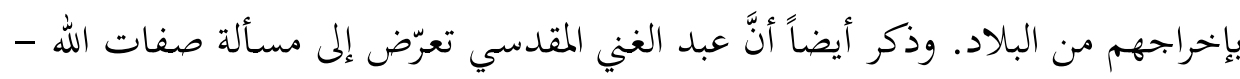

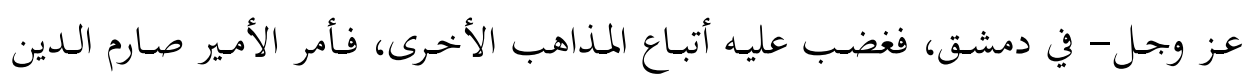
برغش بنفيه من البلد، وأرسل الأسارى من القلعة، فكسروا منبر الحنابلة، وتعطلت يومئذ صلاة الظهر في محراب الحنابلة.

إنَّ مبدأ حرية الاختيار منسجم مع مقاصد الشريعة لاحترام العقل الإنساني والكرامة

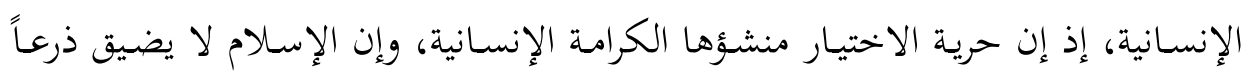

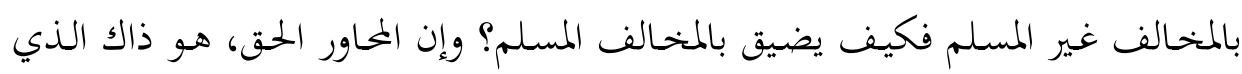

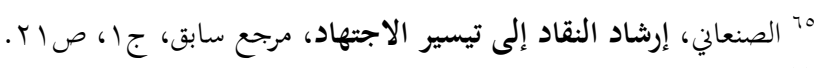

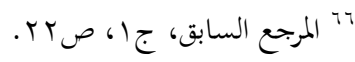


ينطلق في حواره مع مخالفه في النحلة، والمذهب من مبدأ حق الآخر بالاختلاف، على أساس أنّ الاختلاف في الأفهام، والاجتهادات، والتوجهات سنةٌ ماضية.

ثالثاً: ضوابط الحوار المذهبي

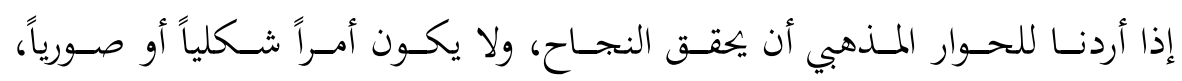
فبالإضافة للمنطلقـات السابقة التي تعد مرتكزات أساسية لنجاحـه، لا بـدّ مـن أن يلتزم بضـوابط قـادرة على تنظيم عمليـة الحـوار، ومــن أهمهـا: التـزام الموضـوعية في الحــوار.

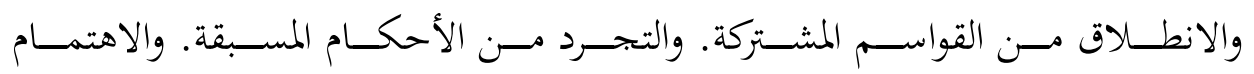

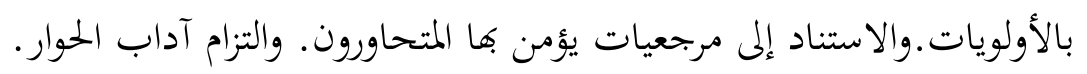

\section{ا ـ التزام الموضوعية في الحوار:}

لا شـكَّ في أنَّ التزام الموضوعية في الحوار، هو مـ أهم الأسس التي ينبغي أن يقوم

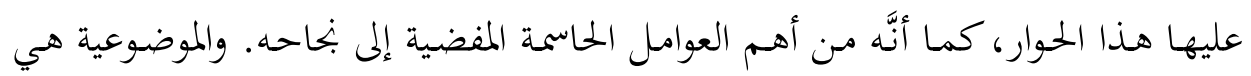

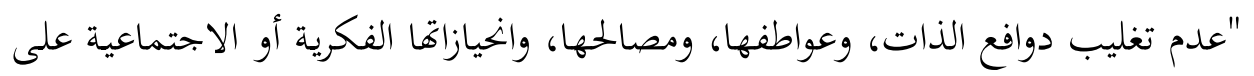

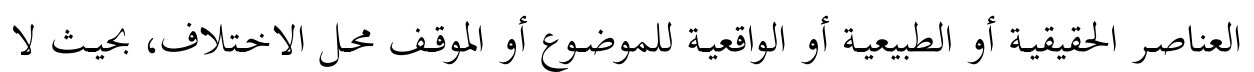

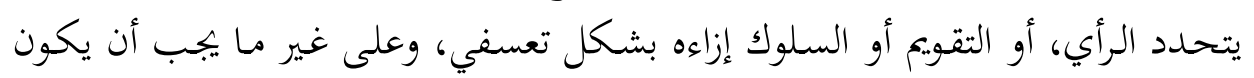

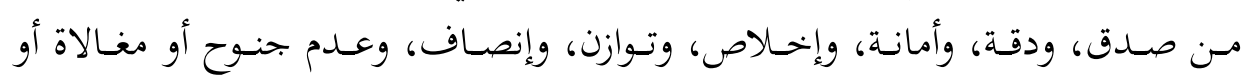
تطرف. من صن

وقد أكّد القرآن الكريم مبدأ الموضوعية الذي غالباً ما كان يعبّر عنه بالعدل في كثير

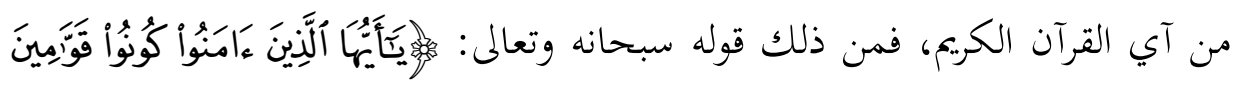

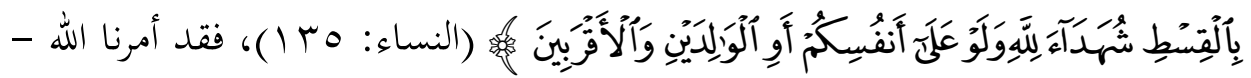

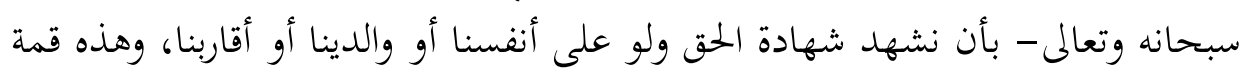

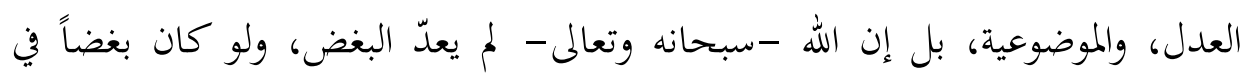

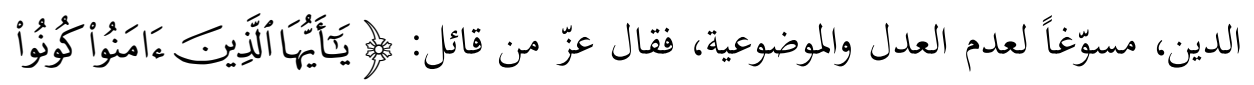

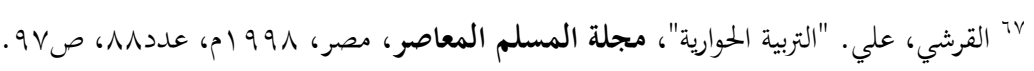




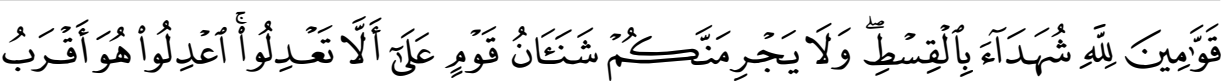

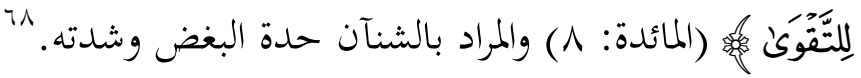

ومن هنا رأينا القرآن الكريم غالباً ما كان يعبّر عن سلوكات المخالف وتصرفاته غير

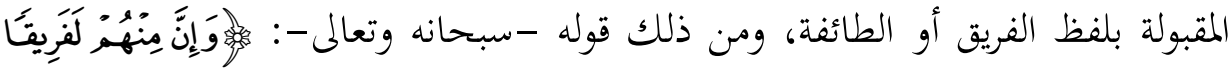

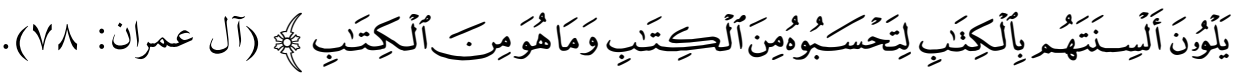

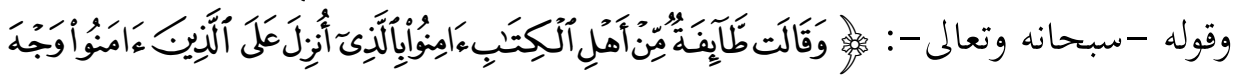

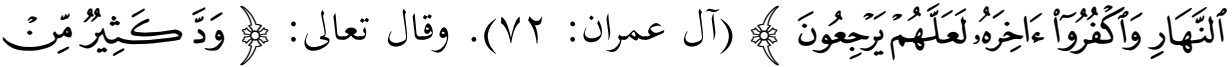

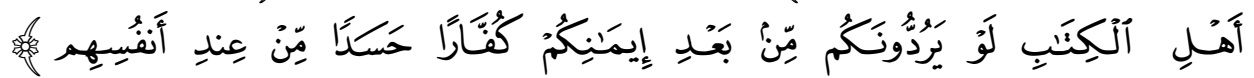

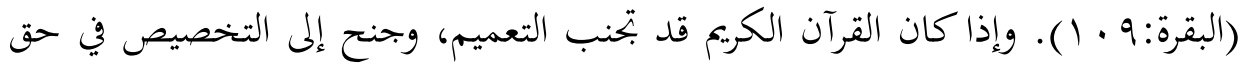
المخالفين في الدين، فتلك هي الموضوعية، التي يرشد الله سبحانه المسلمين إليها، ليتجَنَّبُوا

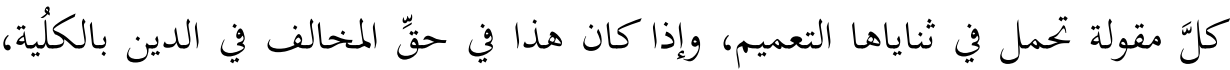

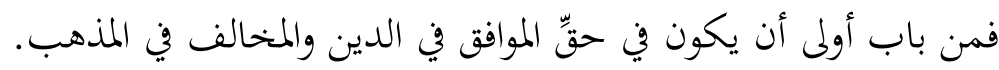

إنَّ الموضوعية في الحكم على الأشياء، حتى لو لم تكن موافقة لمعتقدات المحاور،

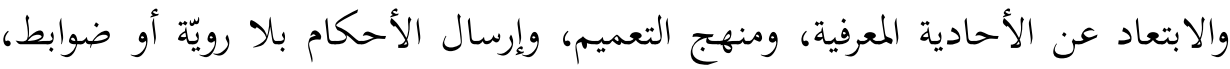

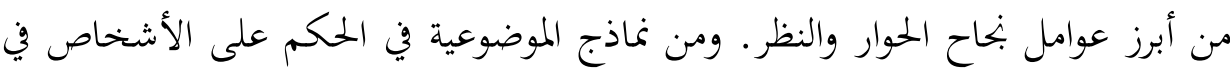

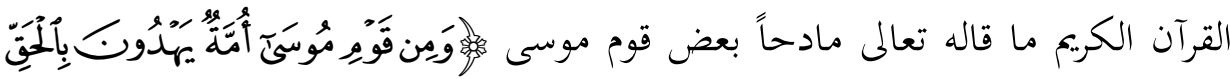

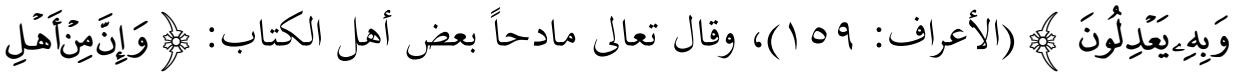

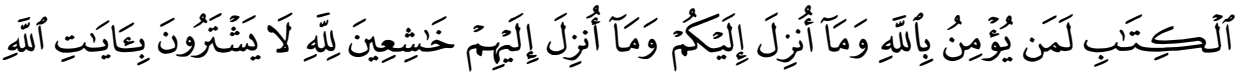

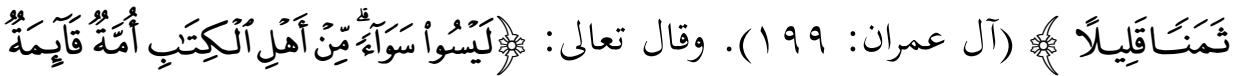

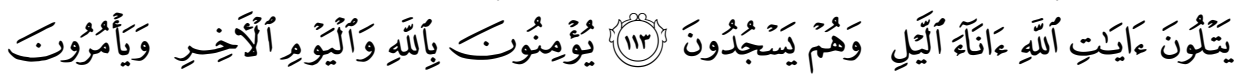

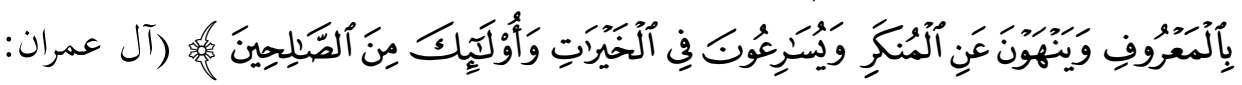

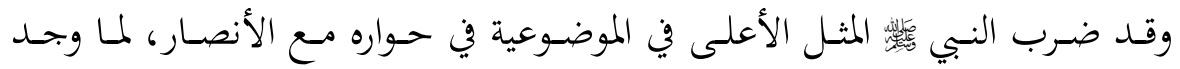

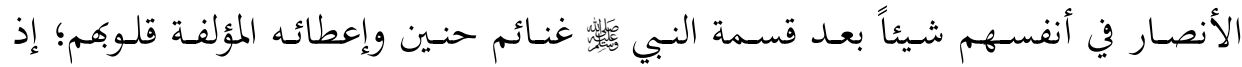


خصّهم بأكثر هذه الغنائم، فأتاهم وخحاطبهم قائلاً: "يا معشر الأنصار ألم آتكم ضُألالاً

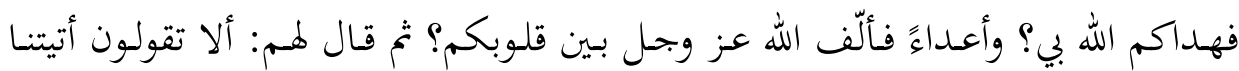

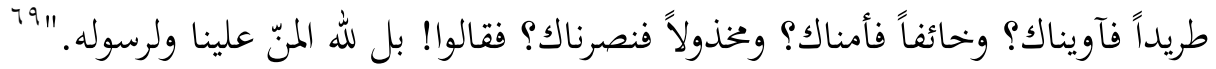
فمن الحمديث نرى -عليه الصلاة والسلام- يلقن الأنصار الحجة التي يحاورونه بها، وهذه أقصى درجات الموضوعية التي يمكن أن يرتقي إليها الفكر الحواري عموماً.

ودأب علماء الحديث على قبول خبر المبتدع إذا كان في نفسه صالحاً، وإذا لم يكن

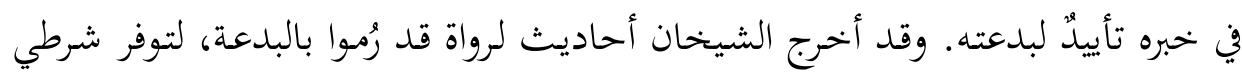

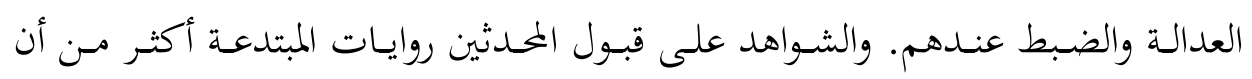
تحصى، وفيما يأتي طرف منها:

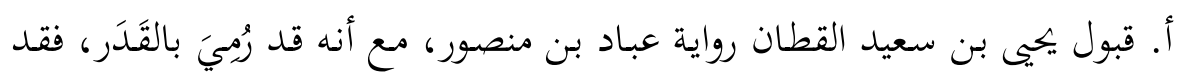

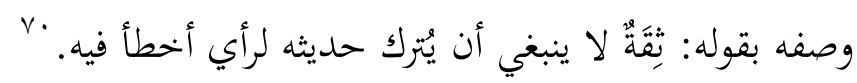

ب. سئل يميى بن معين عن سعيد بن خثيم فقال: ليس به بأس، ثِقة، فقيل له:

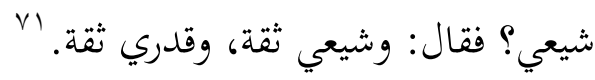

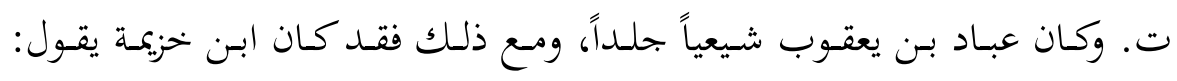

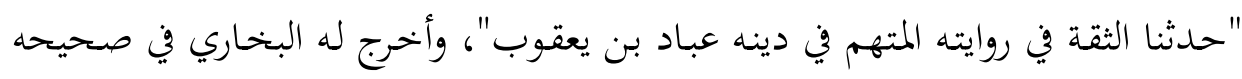

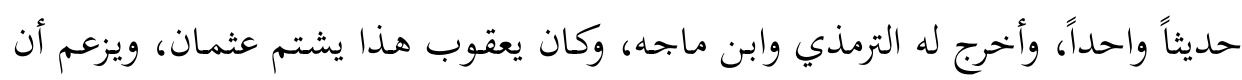

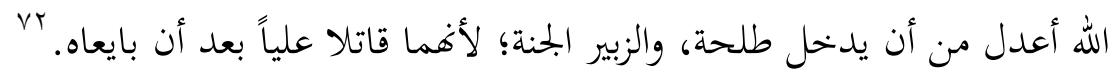

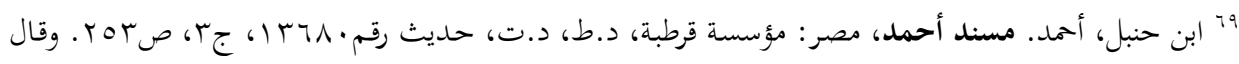

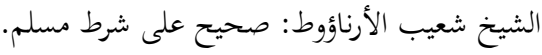

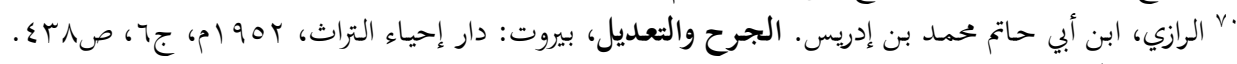

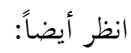
- ابن حجر العسقلاني، أمد بن علي. تهذيب التهذيب، مدينة الشر: دار الفكر للطباعة والنشر والتوزيع،

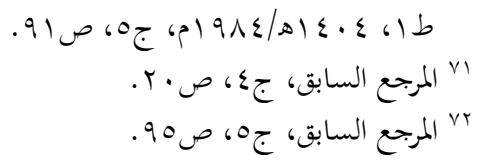




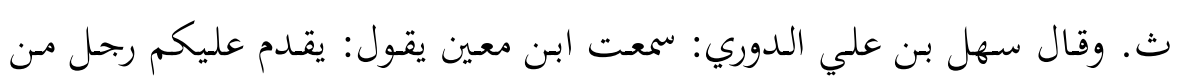

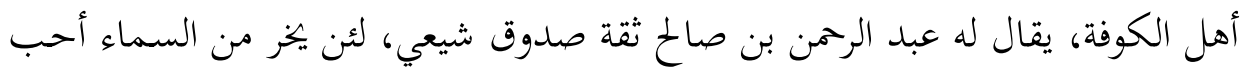

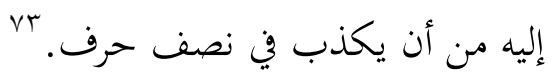

ج. وقال يعقوب بن يوسف المطوعي: كان عبد الرحمن بن صالح رافضياً، وكان

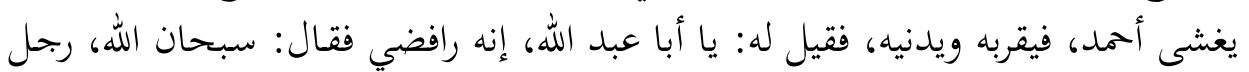

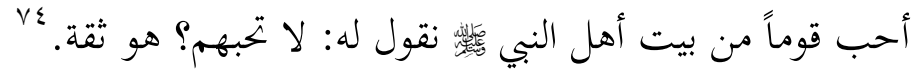

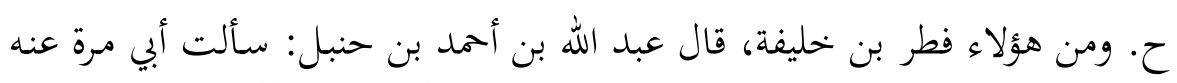

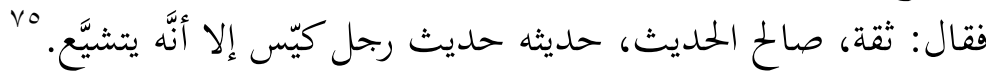

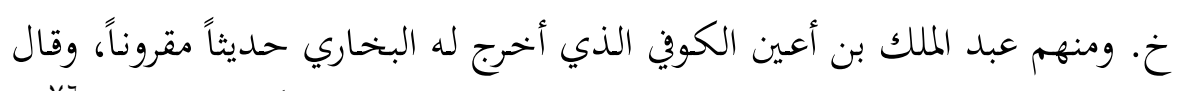

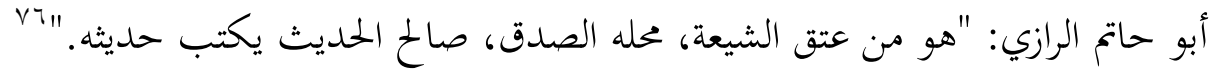

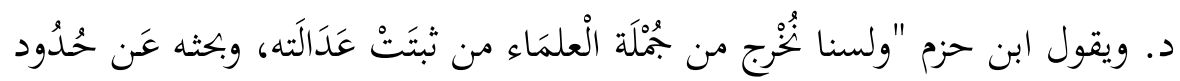

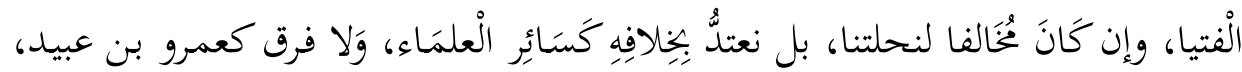

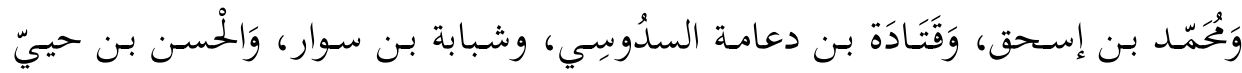

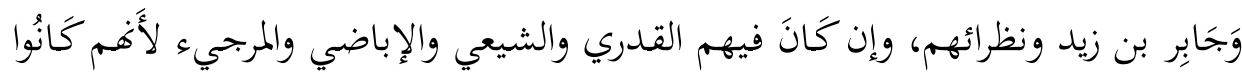

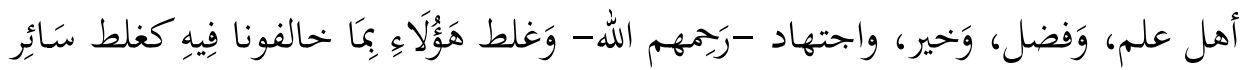

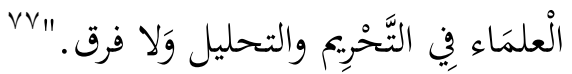

وبناء على ذلك كله، فإنَّ الموضوعية تستلزم بالضرورة عدم ادّعاء احتكار الحقيقة؛

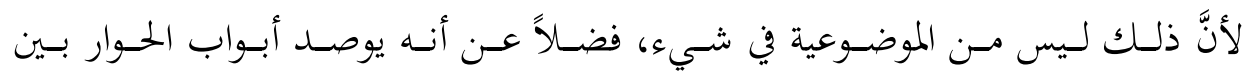
المتحاورين، بل وربما قلب الحوار إلى جدل سفسطائي غير ذي ثمرة، ولا فائدة. جr الخطيب البغدادي، أحمد بن علي. تاريخ بغداد، تحقيق: مصطفى عبد القادر عطا، بيروت: دار الكتب العلمية،

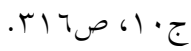

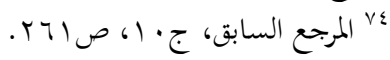

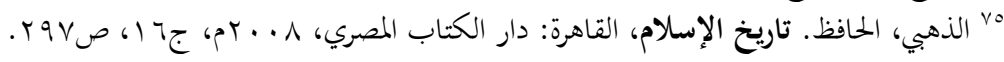

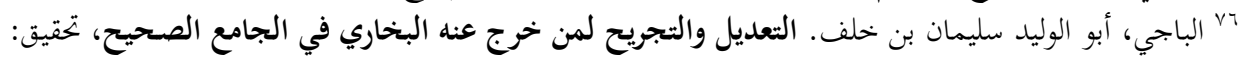

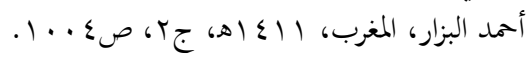

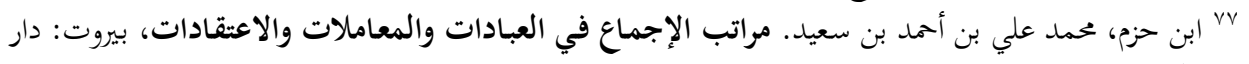

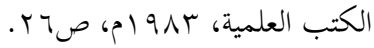




\section{r ب الانطلاق من القواسم المشتركة:}

إنَّ ما يجمع هذه الأمة من المعتقدات أكثر بكثير محا يفرقها، وإن الانطلاق من القواسم المشتركة يعني بالضرورة تحديد نقاط الاتفاق، وتعظيمها والانطلاق منها. ولقد

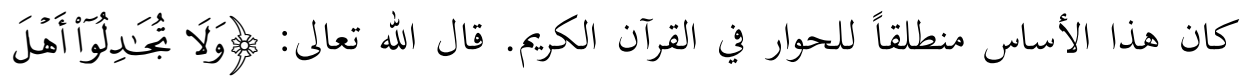

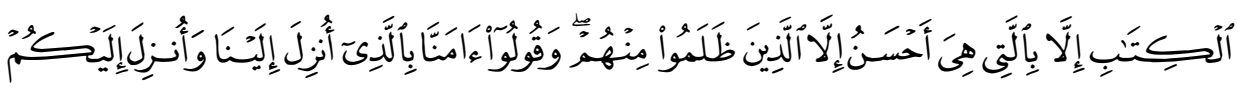

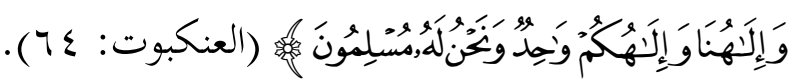
وواضح من الآية المتقدمة أن الله -سبحانه وتعالى- قد أمرنا بالانطلاق من القواسم المشـتركة في حوارنـا حستى مـع الـذين ظلمـوا مـن أهـل الكتاب، كمــا أمـر الله -سـبـحانه وتعالى - نبيه أن يحاور أهل الكتاب من خلال التركيز على نقاط الاتفـاق بيننا وبينهم،

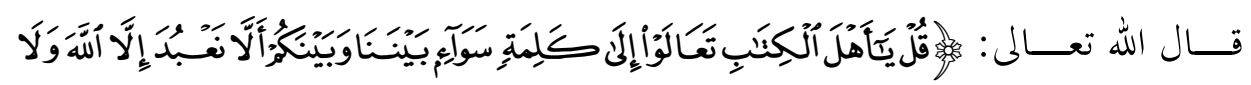

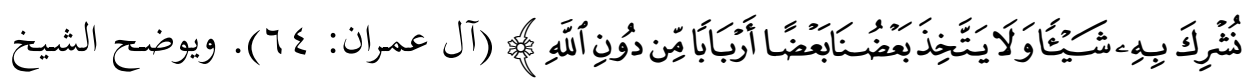
محمد عبده كيفية التركيز على نقاط الاتفاق، والمحاورة في نقاط الاختلاف من خحلال هذه

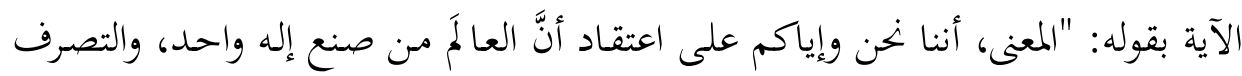

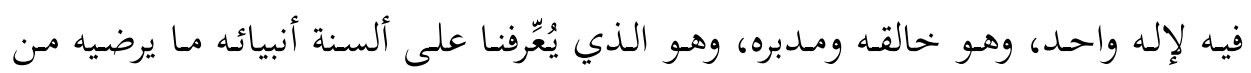

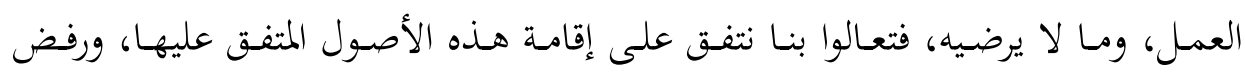

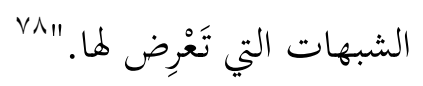

والبـدء بنقـاط الاتفـاق يشيع نوعـاً مـن الألفـة، والمـودة بـين المتحـاورين المختلفـين في

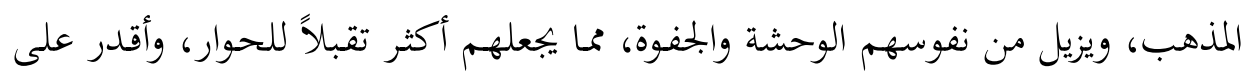

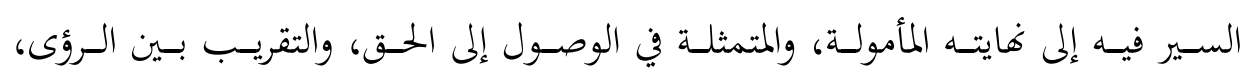

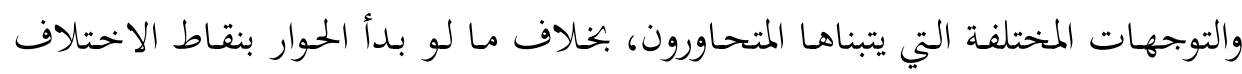
الذي سيؤدي إلى تنافر بين المتحاورين، ومحاولة انتصار كل ذي مذهب لمذهبه، بل ولربما 


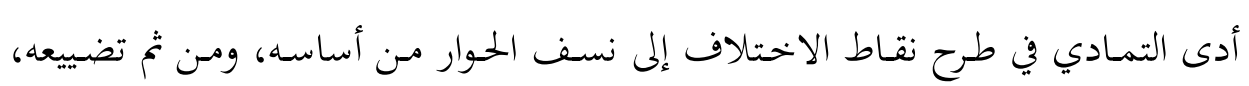

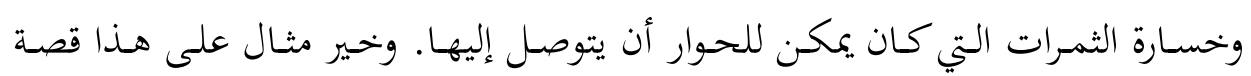

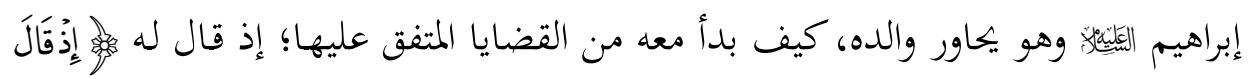

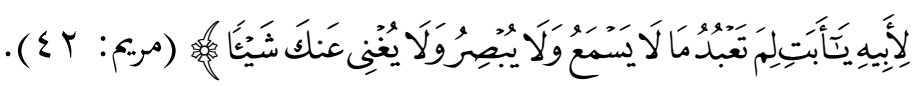
إنَّ البده بالقواسم المشتركة يعني تحديد نقـاط الاتفـاق بدقة، وتأكيدها واحسدة بعد

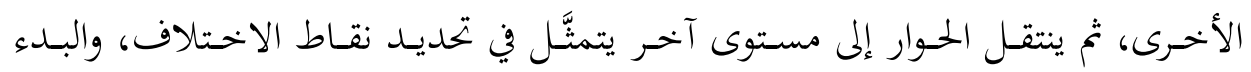

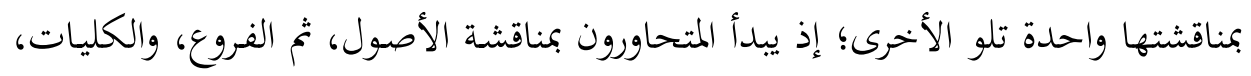

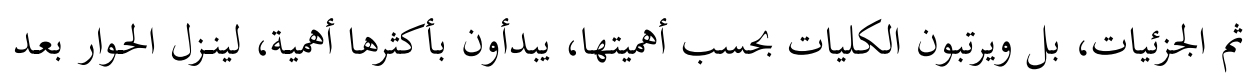
ذلك إلى أقلها وهكذا.

وبناءً عليه، فإنَّ المنتمسين إلى مذاهب مختلفة داخل دائرة الإسلام، لا بدّ أن ينطلقوا

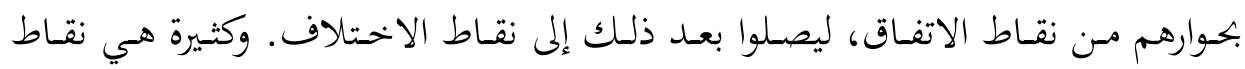

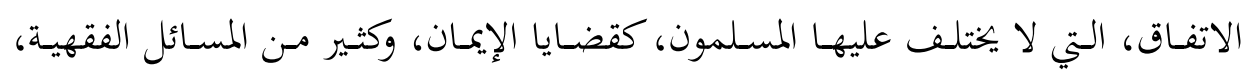
كوجوب الصلاة، والزكاة، والصيام، والحج وغير ذلك، غير أن هذا لا يعني بحال الاتفاق

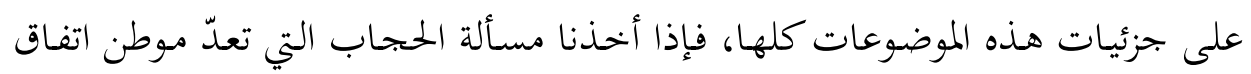

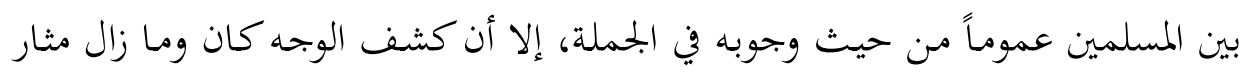

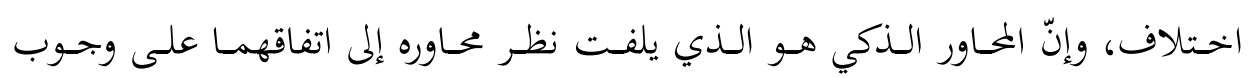
الحجاب، ثم يهاول إقناعه بما يراه في مسألة كشف الوجه، وهكذا وهي في المسائل كلّها التي يتفق المسلمون على أصلها، ويختلفون في تفاصيلها.

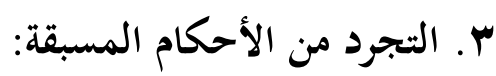

من أجل إدارة حوار ناجح ومفيد، لا بدّ من التجرد، حين الدخول إلى ذلك الحوار،

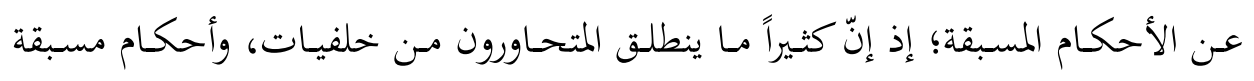
Pa9 الصويان، أحمد بن عبد الرممن. الحوار أصوله المنهجية وآدابه السلوكية، الرياض: دار الوطن للنشر، طال، 


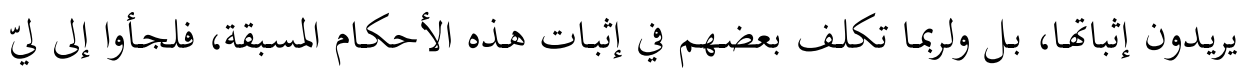

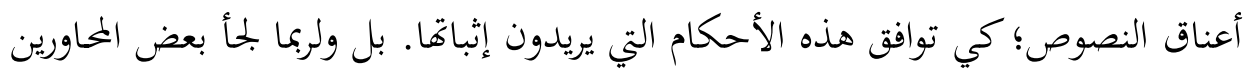

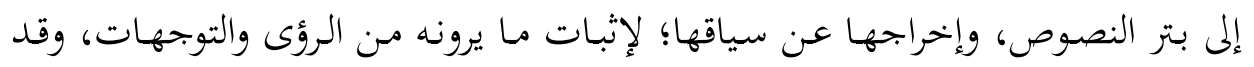

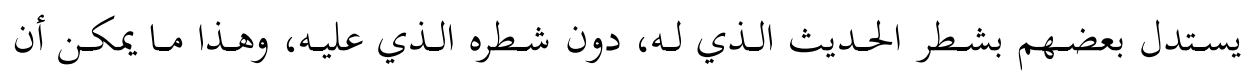

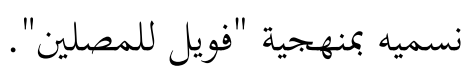

ينبغي للحوار حتى يكون ناجحاً، وذا ثمرة، وفائدة، ومفضياً إلى النتائج المأمولة، أن

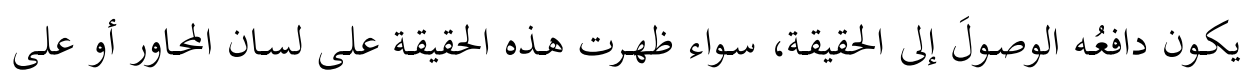

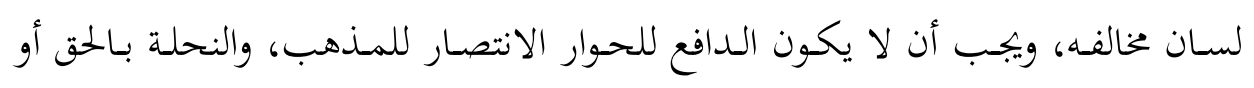

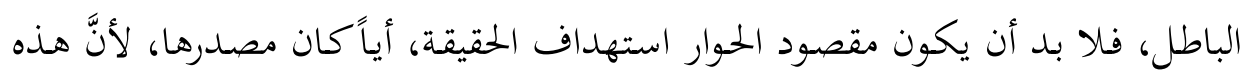
الحقيقة هي ضالَّة المؤمن.

وقد أرشدنا القرآن الكريم إلى ضرورة عدم الانطلاق من الأحكام المسبقة، حتى كئى

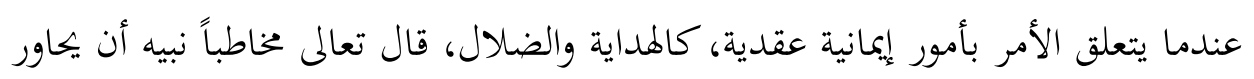

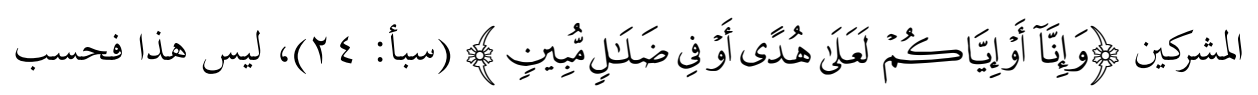

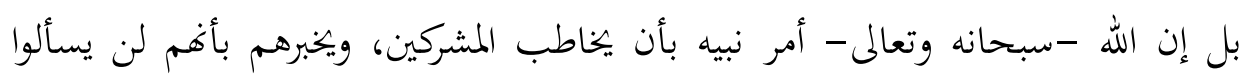

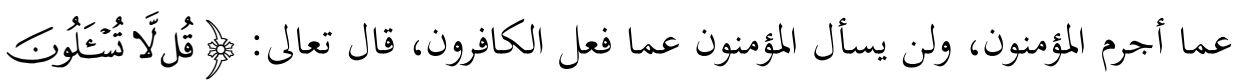

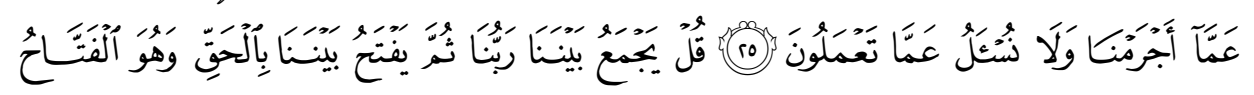

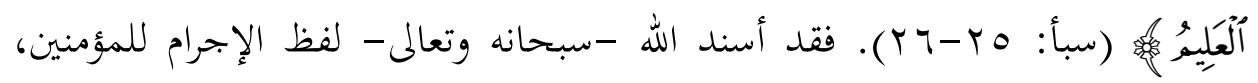

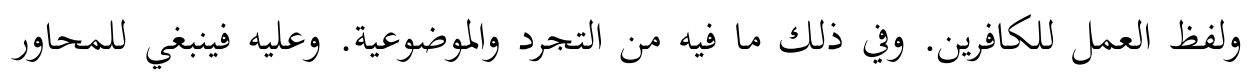

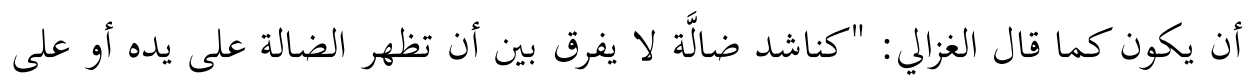

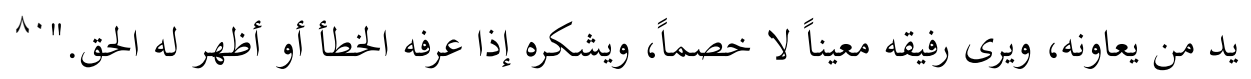
وقد تمثَّل علماؤنا الأوائل هذا المعنى الذي أشار إليه الغزالي، فها هو الشافعي يقول:

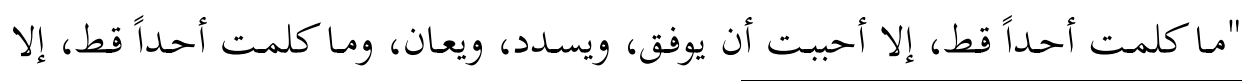

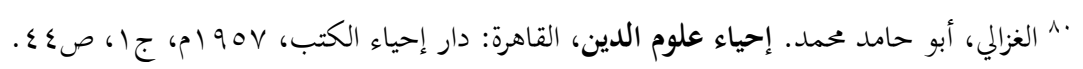




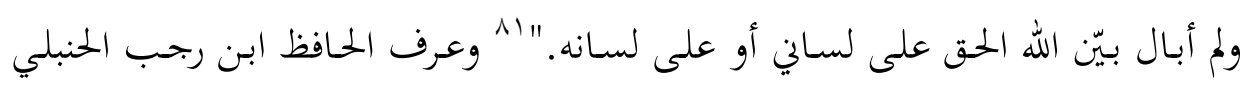

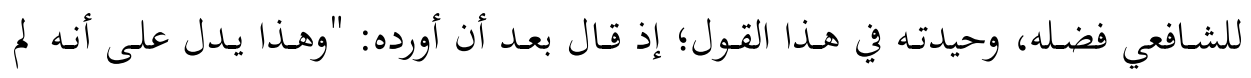

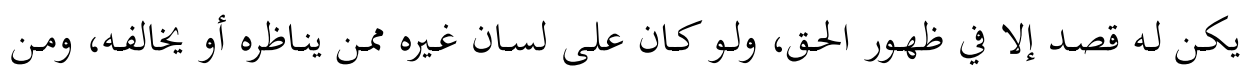
كانت هذه حالُه، فإنَّه لا يكره أن يرد عليه قوله.

والتجرد عن الأفكار والأحكام المسبقة يعني التسليم بإمكانية أن يكون الصواب مع

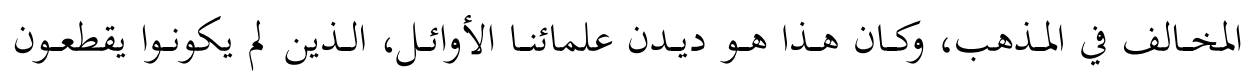
بصواب مذهبهم وبطلان مذهب المخحالف، روي عن أبي حنيفة "أنه كان إذا أفتى يقول:

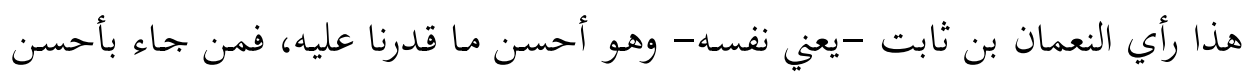

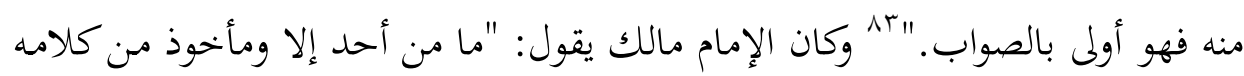

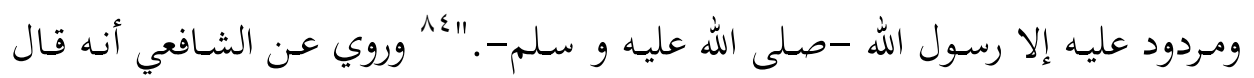

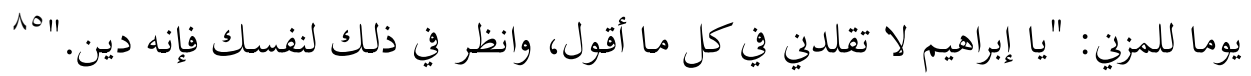

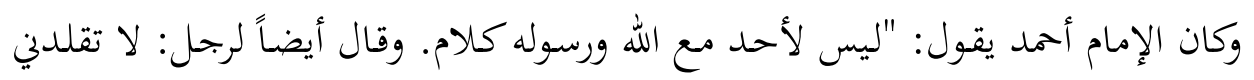

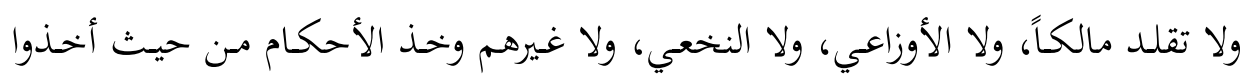

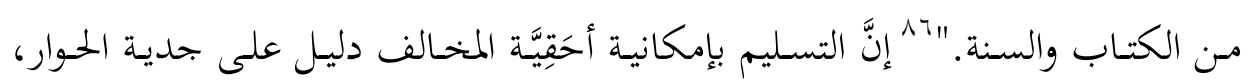
ورغبة المتحاورين في الوصول إلى الحق.

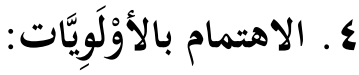

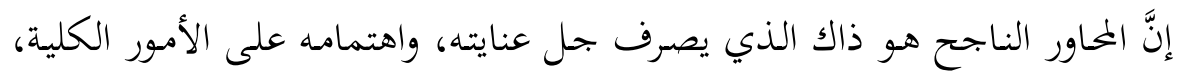

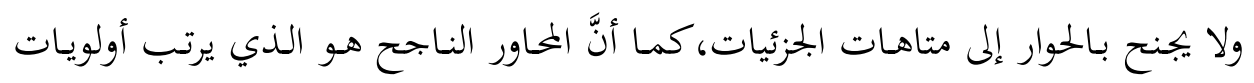

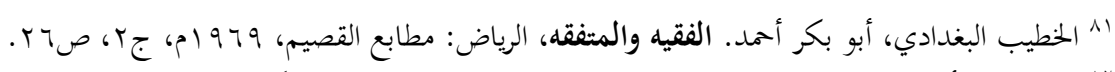

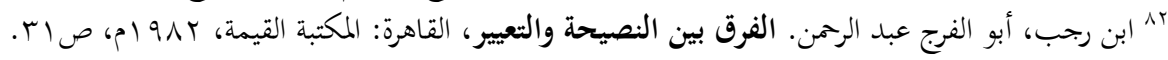

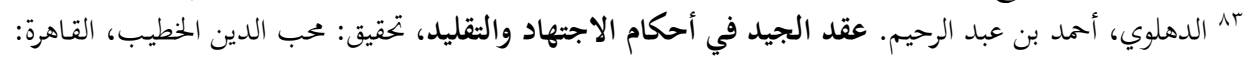

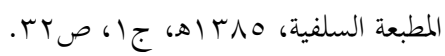

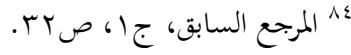

$$
\begin{aligned}
& \text { 10 المرجع نفسه. } \\
& \text { 14 المرجع نفسه. }
\end{aligned}
$$


الحوار، فيبدأ بالأمور الأكثر أهمية، وأولوية، التي يترتب على بقاء الاختلاف فيها أثر كبير

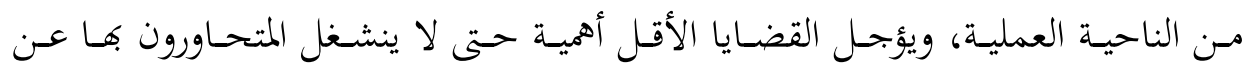
القضايا الرئيسة التي تشكل أولويات للحوار.

كان الاهتمام بالأولويات، والبداية بها دَيْدنَ القرآن، فقد ركزت المرحلة المكية على أمور العقيدة مـن: الإيمان بـالله، وتوحيده، ونبـ الشرك، وعبـادة الأصنام، كما تم التركيز

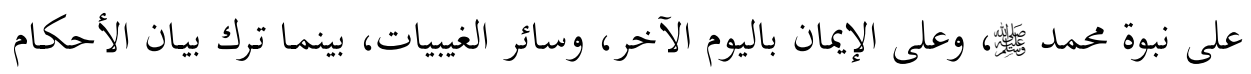

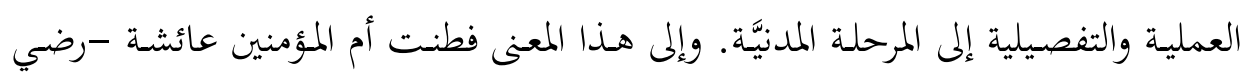

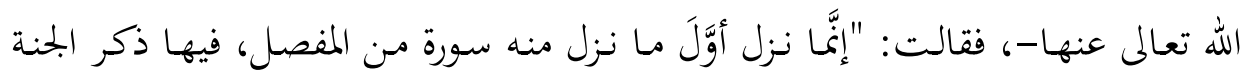

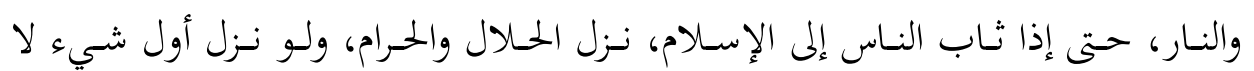

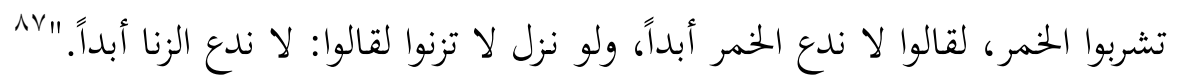

\section{ه. الاستناد إلى مرجعيات يؤمن بها المتحاورون:}

مـن المعلوم بداهـة أنَّ أهـم مـرجعيتين يـؤمن بهمـا المسـلمون على اخـتلاف نحلهـم،

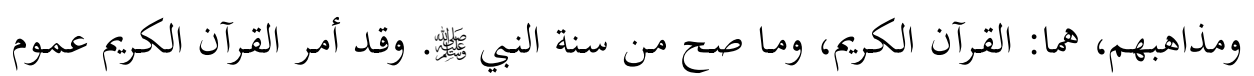
المسـمين بالاحتكام إلى هـاتين المرجعيتين عند التنـازع، ومـن المفترض أن يرفع الاحتكام

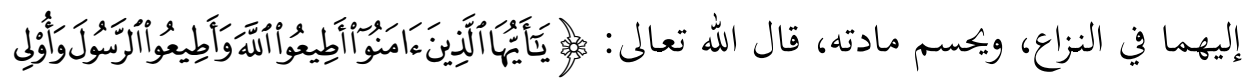

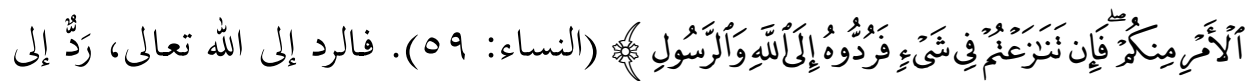

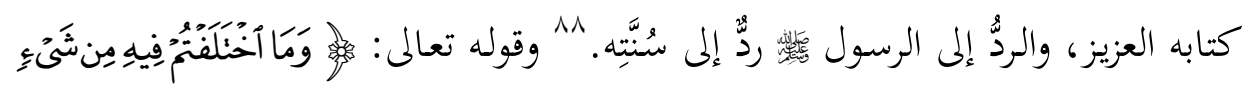

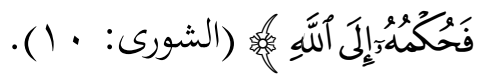
والاحتكام إلى المرجعية التي يؤمن بها المتحاورون له أثر في حسم مادة النزاع، وذلك

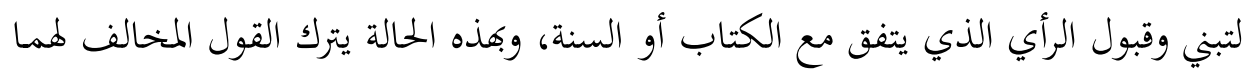

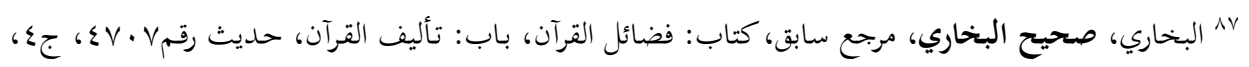


للقول الموافق، قال ابن تيمية: "فإذا تنازع المسلمون في مسألة، وجبب ردّ مـا تنازعوا فيه

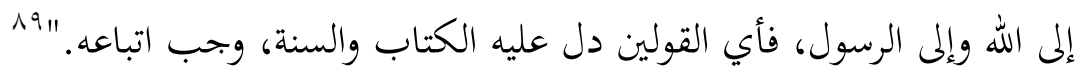

إنّ عـدم الاحتكـام إلى مرجعيـة يـؤمن بهـا المتحــاورون، سـيترتب عليـه أبلـغ الضـرر

بالعملية الحوارية؛ لأن المحاور إذا لم يؤمن بدليل مخالفه، فلن يتوصل معه إلى رأي يتفقان

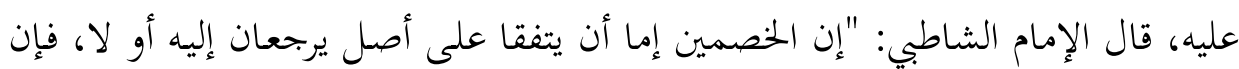
لم يتفقا على شيء لم يقع بمناظرةما فائدة بحال، وإن كانت الدعوى لا بدّ لها من دليل، وكان الدليل عند الخصم متنازعا فيه، فليس عنده بدليل، فصار الإتيان به عبثاً لا يفيد بفائدة، ولا يكصل مقصوداً. ومقصود المناظرة رد الخصسم إلى الصواب بطريق يعرفه؛ لأن رده بغير ما يعرفه مـن بـاب تكليف مـا لا يطاق، فلا بـدّ مـن رجوعهمـا إلى دليل يعرفه

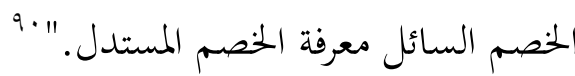

$$
\begin{aligned}
& \text { 7. التزام آداب الحوار: }
\end{aligned}
$$

إنَّ كثيراً من الحوارات التي تتم فيما بين المسلمين، تبتعد عن آداب الحوار وسلوكاته،

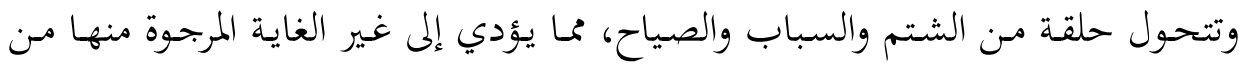
التقارب، والتفاهم، والالتقاء، إلى التباغض، والتباعد، والقطيعة، وتعميق الخلاف، وإثارة

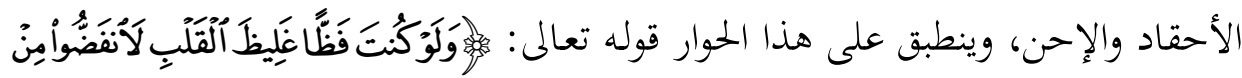

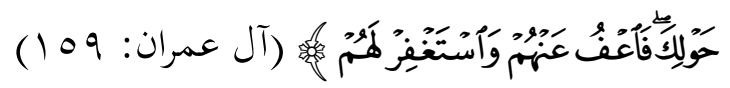

وإنَّ من آداب الحوار أن يكون المحاور على علم بما يحاور به، وقد نعى القرآن الكريم

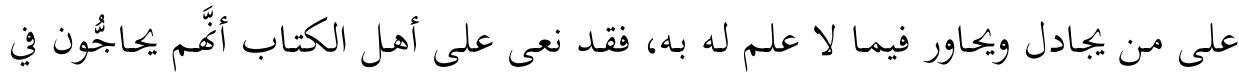

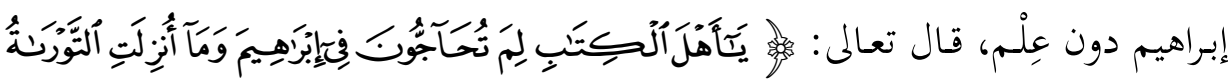

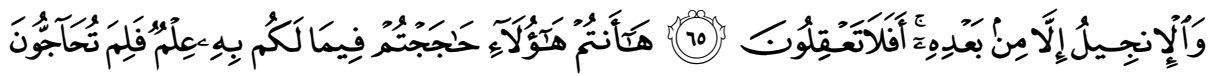

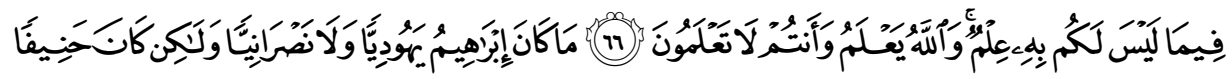

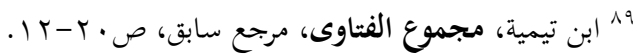

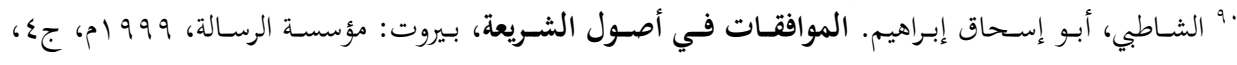




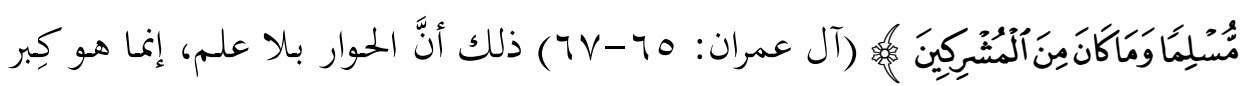

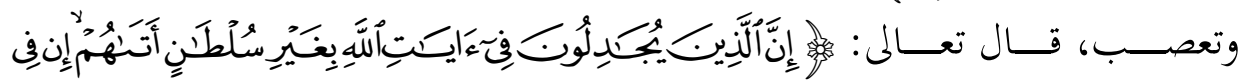

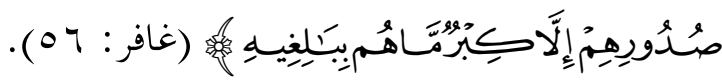

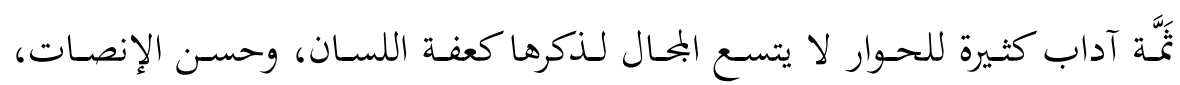

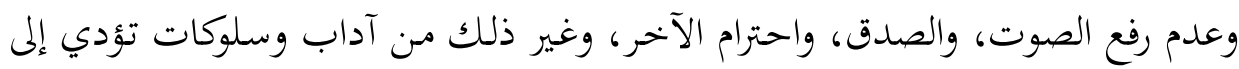

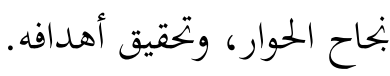

خاتمة:

إنَّ الحهوار المـذهبي هـو حتمية إسلامية لا بـدّ منهـا مـن أجل توحيد جهود الأمهة،

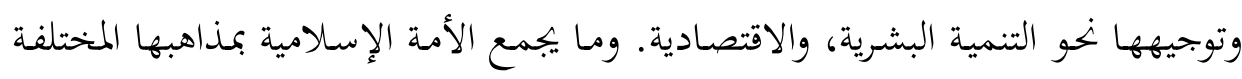

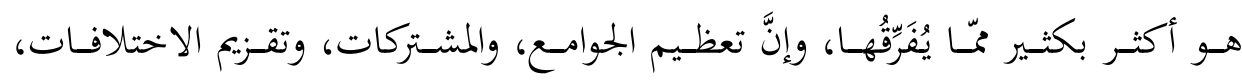

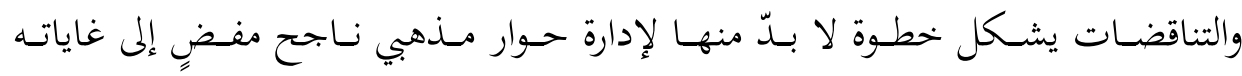

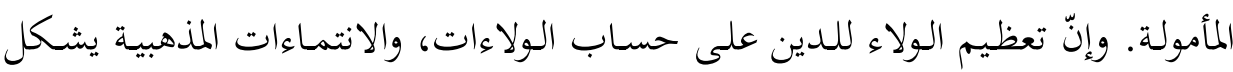

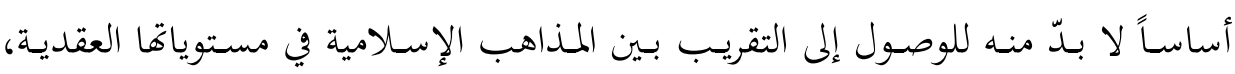

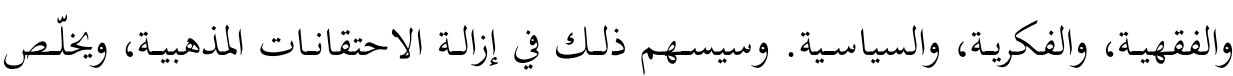

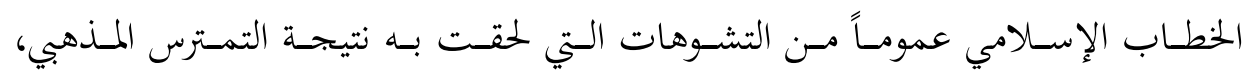
والتجييش الطائفي، والتخندق الحزبي.

إنّ مشروعية الاختلاف لا تنفي ضرورة أهمية العمل، للوصول إلى الاتفاق فيما يمكن

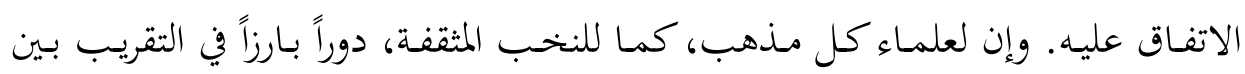

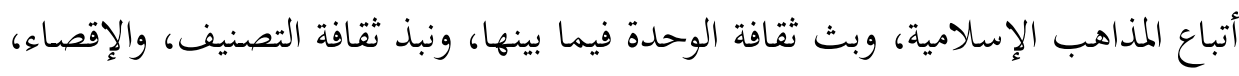

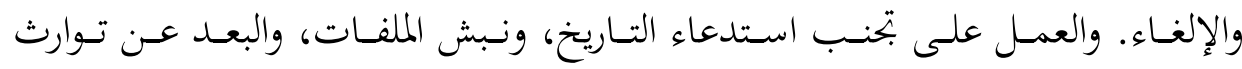

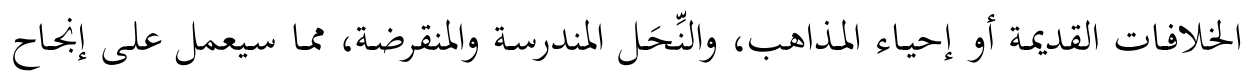
الحوار بين المذاهب الإسلامية، ووصوله إلى فاياته المأمولة، وغاياته المرتجاة. 
وبناء على ما سبق، فإن الدراسة توصي بما يأتي:

- - ضـرورة قيـام مؤسسـات علمى مسـتوى العـا لم الإسـلامي، تعنى في التقريسب بـين

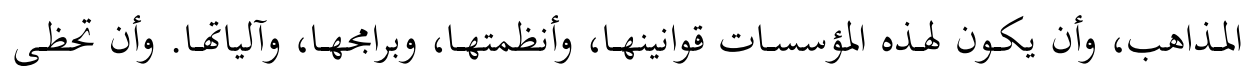
بالدعم المالي، والمعنوي من السلطات السياسية في كل دولة من دول العالم الإسلامي. - - أن تقوم منظمة المؤتمر الإسـلامي بإنشاء دائرة أو مؤسسة، يكون مـن أهـافها إدارة الحوار بين المذاهب الإسلامية في مستوياقا المختلفة، وأن تقدم هذه المؤسسة تقريراً مفصلاً عن عملها لمؤتمرات وزراء خحارجية الدول الإسلامية أو للقمهم الإسلامية بشكل دوري.

- - تضمين المناهج التعليمية في المراحل المختلفة مباحث، ومساقات تشجع الحوار بين المذاهب الإسلامية، وتبث في الطلبة الوعي بوحدة الأمة الإسلامية، وضرورة التسامي فوق الخلافات المذهبية. - تنقيـة المنـاهج، والخططط الدراسـية لكليـات الشـريعة، والدراسـات الإسـلامية في

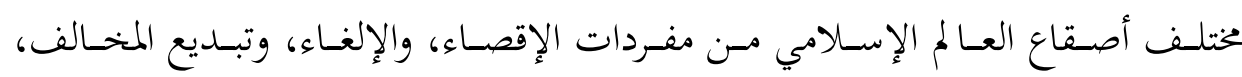
وتفسيقه، وتكفيره، والاستعاضة عن ذلك كله بتوهيمه أو تخطئته عند الضرورة، وبما تمليه مقتضيات البحث العلمي. - - ضرورة قيام كليات الشريعة في العالم الإسلامي بتدريس الفقه المقارن الذي يزود الطالب بالملكة الفقهية، ويجعله أكثر قدرة على استيعاب المخالف وتفهمه وإعذاره. - تخليص الخطط الدراسية في كليات الشريعة، وأقسام الدراسات الإسـلامية مـن أي مبحث أو مساق يتحدث عن فرق مندرسة أو منقرضة، لما يحمله هذا الحلديث من إحياء لخلافات ميتة.

- - عقد الندوات والمؤتمرات بين علماء الأمة الإسلامية، للتباحث في السبل العملية لتوحيد الأمة، والتقريب بين مذاهبها، بعيداً عن الأكاديمية المحردة، أو التنظير الجامد. 


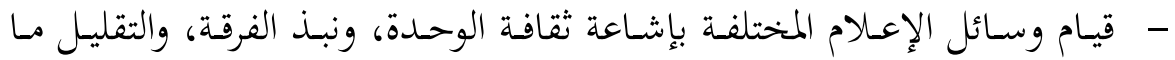

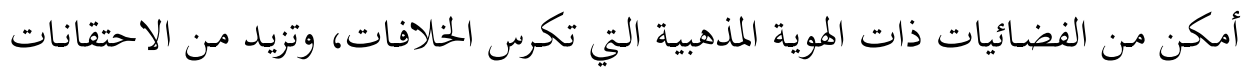
المذهبية.

- - تبادل الزيارات بين الأساتذة في الجامعات الإسلامية، وتبادل المؤلفات مما يكفل تفهما أفضل للمخالف في المذهب والنحلة. - إقامة مراكز مشتركة للأبحاث تكون مهمتها تنقية التراث الإسلامي عموماً من أدبيات التكفير، والتضليل، والتفسيق، والتبديع. مران. - العمل على قيام وفود تضم النخب من العلماء المعتدلين، تقوم بتبادل الزيارات

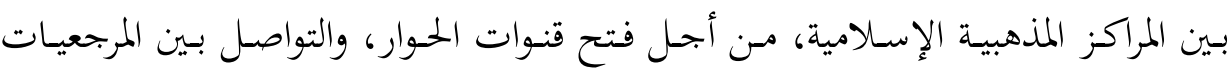
الإسلامية المختلفة.

- - إنشاء المواقع الإلكترونية على الشبكة العنكبوتية التي تبـث ثقافة التقريب بين

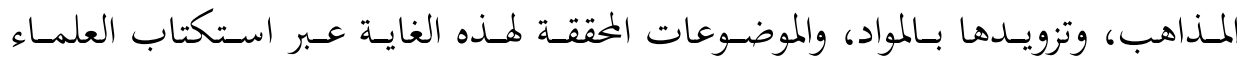
المعتدلين، والموضوعيين من المذاهب الإسلامية المختلفة. - - نشر المطبوعات التي تشيع ثقافة الوحـدة، وتحاصر ثقافة الانزواء، والانغلاق، والتمترس خلف الهوية المذهبية. 